\title{
Examining the Potential Benefits of Internal Control Monitoring Technology
}

\author{
Adi Masli \\ University of Arkansas \\ Gary F. Peters \\ University of Arkansas \\ (Corresponding Author) \\ Vernon J. Richardson \\ University of Arkansas \\ Juan Manuel Sanchez \\ University of Arkansas
}

September 2009

We thank Jim Hunton (editor), Steven Kachelmeier (senior editor), and two anonymous reviewers for their helpful guidance. We appreciate the helpful comments from Alberto Dorantes, Michael Ettredge, Robert Fuller, Suzanna Hicks, Diane Janvrin, Tina Loraas, Terry Neal, Ed O'Donnell, Arianna Pinello, Marcia Watson and workshop participants at the 2008 KPMG PhD Project Conference, 2009 AAA AIS Mid-Year Conference, 2009 AAA Auditing Mid-Year Conference, 2009 University of Waterloo Symposium on Information Integrity and Information Systems Assurance, University of Arkansas and University of Tennessee. The authors gratefully acknowledge the financial support of the Information Technology Research Institute at the Sam M. Walton College of Business. Juan Manuel Sanchez acknowledges financial support from the KPMG Foundation. 


\title{
Examining the Potential Benefits of Internal Control Monitoring Technology
}

\begin{abstract}
We analyze the potential benefits that firms can realize from implementing technology specifically aimed at monitoring the effectiveness of their internal control systems. The Committee of Sponsoring Organizations of the Treadway Commission asserts that effective internal control monitoring should enhance the efficiency of internal control processes, and in turn, the assurance over such processes (COSO 2009a). We develop hypotheses to test the realization of these potential benefits. Specifically, we identify a sample of firms that implemented internal control monitoring technology in response to the internal control requirements of the Sarbanes-Oxley Act. Consistent with our hypotheses, we document that the implementation of internal control monitoring technology is associated with lower likelihood of material weaknesses, smaller increases in audit fees, and smaller increases in audit delays during the post-SOX time period. We discuss the potential implications of our findings for research related to continuous monitoring, client-provided assurance assistance, and information technology governance.
\end{abstract}

Key Words: Internal Control Monitoring, Material Weakness, Audit Fees, Audit Delays

Data Availability: Data are available from public sources identified in the article. 


\section{INTRODUCTION}

Expanding regulatory and business pressures have greatly increased the demand for and the sophistication of effective internal control monitoring (ICM) (Coderre 2006; PwC 2006b). The Committee of Sponsoring Organizations of the Treadway Commission (COSO) asserts that improved ICM practices should enhance the efficiency, effectiveness and assurance of internal control processes (COSO 2009a). ${ }^{1}$ In January 2009, COSO (2009a, 2009b, 2009c) issued guidance on ICM and observed that firms often struggle with realizing the benefits of ICM-related activities. The purpose of the current study is to examine the potential benefits that firms can realize from implementing ICM technology designed to support and facilitate internal control processes.

While the concept of ICM is theoretically valuable, we are unaware of any objective evidence documenting the benefits asserted by COSO and others. Our analysis is also motivated by practitioners who argue that it is unclear whether the implementation of various information technology initiatives yields the intended benefits (Standish Group 2004; Dewan et al. 2007; ITGI 2008b). External audit partners too have reservations about of the benefits of audit-related information technology (Behn et al. 2006). Thus, the current study holds relevance and importance to multiple stakeholders.

Our research questions involve the internal and external assurance benefits, if any, associated with the implementation of ICM technology initiatives. We develop and test hypotheses for three explicit potential benefits associated with internal and external assurance outcomes: 1) more effective internal control systems, 2) enhanced audit efficiency, and 3) timely audit reporting. We identify 139 announcements of ICM technology purchases across the time period 2003-2006. Our control group consists of all available observations listed in Audit Analytics SOX 404 Internal Controls database during the same periods.

\footnotetext{
${ }^{1}$ Following Hunton et al. (2008) and COSO's guidance on internal control monitoring (COSO 2009a), we adopt a broad theoretical construct of continuous monitoring which includes assurance activities and a wide range of monitoring timeliness.
} 
Consistent with our hypotheses, we document positive associations between ICM technology initiatives and subsequently stronger internal controls (i.e., lower likelihood of material weaknesses), enhanced audit efficiency (i.e., smaller increases in audit fees) and timely audit reports (i.e., smaller increases audit report delays). Collectively, our main results suggest that ICM technology yields important benefits in both internal and external assurance outcomes. In some of our tests (i.e., audit report delays), our findings suggest transformativeoriented ICM technology initiatives yield greater assurance benefits compared to complianceoriented ICM initiatives.

Our study makes three primary contributions to the accounting and auditing communities of researchers, practitioners, and regulators. First, to our knowledge, ours is the first study to document economically significant benefits consistent with COSO's assertions that formal ICM activities enhance the strength of internal control systems and the efficiency of external examinations of such internal control systems. ${ }^{2}$ Given the steep costs of reporting material internal control weaknesses (Gupta and Nayar 2007; Hammersley et al. 2008; Ashbaugh-Skaife et al. 2009) and unprecedented rise in assurance costs (Raghunandan and Rama 2006; Krishnan et al. 2008) in the post-SOX environment, our results suggest that ICM technology can help to mitigate such costs. ${ }^{3}$

Second, our study contributes to the literature in accounting information systems (AIS) by documenting specific benefits associated with strategically focused information technology (IT). Prior AIS research documents mixed results with respect to the benefits of IT implementations (e.g., Tam 1998; Hunton et al. 2003; Kobelsky et al. 2008), pointing out that the economic benefits deriving from IT can be elusive (Dehning and Richardson 2002;

\footnotetext{
${ }^{2}$ As discussed in greater detail in the results section of the article, our results suggest that SOX ICM technology yields economically significant benefits, after controlling for other important economic factors identified in prior research. For instance, our point estimates suggest that relative to control firms, in the year after implementation, SOX ICM firms face audit fee increases that are approximately $15 \%$ lower.

${ }^{3}$ For example, Hammersley et al. (2008) and Gupta and Nayar (2007) find a negative stock price reaction to the announcement of material weaknesses and Ashbaugh-Skaife et al. (2009) find a significant increase in cost of capital for these firms. Raghunandan and Rama (2006) find a median increase in audit fees of 128 percent from years 2003 to 2004 .
} 
Melville et al. 2004), partly due to commonly used aggregate performance measures (e.g., ROA) that capture only a part of the benefits generated by IT-related initiatives. In contrast to prior research that focuses on linking broad IT initiatives to broad outcomes (e.g., Hayes et al. 2001; Hitt et al. 2002; Dehning et al. 2003; Hunton et al. 2003; Kobelsky et al. 2008), our study advances this stream of literature by investigating three distinct (non-mutually exclusive) targeted assurance benefits of a specific-use IT. In so doing, we address the call from the ITGA (2005) to document measures of IT benefits that might otherwise be unobserved by traditional financial measures.

Finally, our study enhances the IT-related auditing literature. Some research in this area focuses on the use of IT by auditors and the effect of IT on auditors' judgments (e.g., Messier 1995; O’Donnell and David 2000; Brazel et al. 2004; O’Donnell and Schultz 2003; Bible et al. 2005; Bedard et al. 2007; Dowling and Leech, 2007; Dowling 2009). Other research involves field-based surveys that describe assurance providers' perceptions about the importance and benefits of using audit-related IT (e.g., Fischer 1996; Behn et al. 2006; Janvrin et al. 2008). There is relatively little archival research in auditing regarding the benefits of assurance-related IT. With the exception of Banker et al. (2002), who investigate the extent in which external auditors' investments in IT are associated with audit firm productivity, we are unaware of any archival studies concerning the impact of an auditee's (as opposed to auditor's) implementation of assurance-related technologies. ${ }^{4}$

\section{BACKGROUND}

\section{Internal Control Monitoring and the Use of Technology}

Our examination is partially motivated by recent concerns about unprecedented compliance costs and challenges associated with SOX internal control requirements.

\footnotetext{
${ }^{4}$ The closest exception to this is outside of the assurance-related literature. Brazel and Dang (2008) study the effects of overall enterprise resource planning systems (ERP) implementation on earnings management (discretionary accruals) and earnings timeliness (earnings release dates).
} 
Specifically, in the revision to its standard for auditing internal controls over financial reporting, the Public Company Accounting Oversight Board (PCAOB) expressed unease about greater than expected assurance expenditures and inefficient initiatives related to complying with SOX Section 404 (PCAOB 2007). In response to these concerns, COSO recently issued improved guidance on the use of ICM, noting that many companies were not making the best use of "ongoing monitoring" practices, which in turn may have caused inefficient internal control evaluations (COSO 2009a).

COSO defines the role of ICM as ensuring that internal control continues to operate effectively by promoting good control operations, and enhancing the process of assessing the design and operation of controls (COSO 2009a). By making ICM a priority, organizations can drive their compliance efforts, identify processing errors, and proactively detect fraud (Ernst \& Young 2007). Information technology plays an essential role in the success of ICM implementation. In this light, the SEC has an interest in whether companies have been able to use technology to gain efficiency in evaluating the effectiveness of internal controls (ITGI 2006). COSO explicitly identifies the use of IT as a tool to enhance ICM either through specific "control monitoring tools" or "process management tools." ICM technology encompasses a range of control monitoring tasks, including the automation of routine control tests, enhanced risk assessments, evaluation and documentation of controls, and managing and communicating control assurance activities (COSO 2009b). The goal of ICM is to enhance the overall visibility of the organization to risk and performance through the effective use of technology (KPMG 2008).

To investigate the potential outcomes of ICM as related to assurance outcomes, we identified a sample of firms that implemented specific ICM technology in response to the internal control requirements of the Sarbanes-Oxley Act (SOX). These specific SOX-related tools include many features consistent with the monitoring-related activities, such as the ability to visually map business processes, risk, and internal control information across 
disparate financial and reporting systems. Firms are also able to maintain comprehensive firm-wide control documentation and automatically monitor workflow status, audit trails, and compliance processes in real time. Among their many designs, these products aim to monitor and prevent internal control weaknesses, provide comprehensive and timely enterprise wide documentation, and maintain information and security integrity, all of which support the role of internal control monitoring objectives (COSO 2009a, 2009b).

\section{Measuring ICM Technology Benefits}

Although the intended role of ICM technology initiatives is beneficial by design, this does not negate the need to measure the benefits of such initiatives. Measuring IT performance allows executives to demonstrate the benefits delivered by IT initiatives (ITGI 2005). Management generally has a firm grasp on the costs of IT implementations, but is less certain of the realized benefits. Over the past decade, researchers have documented many cases of expensive IT initiatives that fail, resulting in squandered resources that negatively impact shareholder wealth (Standish Group 2004). For example, the ITGI reveals that approximately 20 to 70 percent of large-scale investments in IT is wasted, challenged, or fails to bring a return to the enterprise (ITGI 2008b). Overzealous product promotion, problematic technology design, poor user acceptance, infrastructure incompatibility, and ineffective maintenance all contribute to IT failure or unrealized benefits of IT implementations. For these reasons, it is particularly important to monitor and evaluate whether IT implementations yield their intended benefits.

AIS and related general information systems literature attempts to address the prior issues by measuring the business value of IT; however, archival evidence regarding the benefit of IT has not always been easy to find. ${ }^{5}$ Part of the difficulty lies in the fact that

\footnotetext{
${ }^{5}$ See Dehning and Richardson (2002) and Melville et al. (2004) for additional reviews of the IT and firm performance literature.
} 
researchers have attempted to link broad IT implementations to broad financial measures of either stock market reaction (e.g., Hayes et al. 2001; Dehning et al. 2003) or firm profitability (e.g., Hitt et al. 2002; Hunton et al. 2003; Kobelsky et al. 2008). The ITGI (2005) notes that traditional performance methods, such as return on investment (ROI), reflect constrained views of IT indirect benefits. As such, they emphasize the importance of measuring direct benefits in order to fully understand how IT contributes to the achievement of business goals.

PricewaterhouseCoopers $(\mathrm{PwC})$ and ITGI note the failure or difficulty faced by firms in measuring or quantifying the benefits of IT-related control initiatives (PwC 2006b, ITGI 2003). These two constituencies observe that when companies measure the performance of IT activities related to control, they limit the measurement to whether a particular technology is in place, as opposed to whether the technology produces beneficial outcomes such as cost savings and risk avoidance. The current study takes an approach of measuring potential outcomes of IT initiatives by considering explicit benefits associated with ICM technology as represented by internal assurance outcomes (i.e., internal control system strength) and external assurance outcomes (i.e., audit efficiency and audit timeliness).

\section{HYPOTHESIS DEVELOPMENT}

\section{Internal Control Effectiveness}

Subsequent to SOX, many studies have focused on the determinants and impact of internal control material weaknesses. Ge and McVay (2005) investigate disclosures of material weaknesses in internal controls and find that weak internal controls are associated with insufficient investment of resources in accounting controls. Ashbaugh-Skaife et al. (2007) and Doyle et al. (2007) also document factors, including organizational complexity, major firm changes, and inadequate resources, which are common to the risk of disclosing internal control weaknesses. In turn, Gupta and Nayar (2007) and Hammersley et al. (2008) find that the market penalizes firms that do not adequately address the above risk factors by 
imposing negative stock price reactions in response to disclosures of internal control weaknesses, particularly if the information describing the weakness is vague and the weaknesses are less "auditable." Despite the importance of meeting the SOX internal control requirements, we know of few studies that investigate the specific strategies used by companies to monitor and assure the effectiveness of internal controls.

Given the potential importance of tools that alleviate the risk associated with internal control weaknesses and the severity of penalties for weak internal controls, we investigate the association between implementations of ICM technology and material control weaknesses. Consistent with many of the functions of ICM technology, described earlier, its purported principal contribution includes the management of risks through the monitoring of a firm's internal controls. ICM technology products focus on guiding the overall process for monitoring and assuring compliance with the SOX Section 404 requirements. Specific functions include the central data repository, responsibility assignment, communication, scheduling, and signing-off of applicable control tests and SOX tasks. These features allow management and assurance teams a greater level of confidence regarding the status of a firm's internal control over financial reporting.

Consistent with the COSO's description of the monitoring process, the aforementioned technology can also represent specific internal control activities (COSO 2009a). These features often include processes for establishing security policies, activities for upholding information integrity, monitoring tools for managing business systems and risk, screens for alerting accounting irregularities, and tools for maintaining segregation of duties. Collectively, effective implementation of ICM technology should improve firms' prospects for avoiding internal control weaknesses. As such, we predict the following hypothesis:

H1: Firms implementing ICM technology will exhibit a lower likelihood of experiencing material internal control weaknesses subsequent to ICM technology implementation. 
Even though this directional hypothesis follows intuitively from the features of ICM technology, it is unclear whether such IT implementations would actually yield subsequent benefits. As discussed earlier, an ongoing challenge for managers has been the ability to measure IT-related initiatives in terms of outcomes (e.g., effective internal control monitoring). Likewise, IT research finds tremendous failure rates of many IT initiatives, with one estimate suggesting that less than 8 percent of IT budgets are actually spent on initiatives that bring benefits to the enterprise (ITGI 2008b).

\section{Audit Efficiency}

Many of the touted features of ICM technology aim directly at the role of external assurance providers and "cost-effective" ways to improve the efficiency of complying with the expanded integrated audit requirements of SOX. For example, COSO (2009b) asserts:

"A properly designed and executed monitoring program helps support external certifications ... because it provide persuasive information that internal control operated effectively at a point in time or during a specific period" (49).

Likewise,

“...organizations might be able to enhance the efficiency of external parties' work by directing them to portions of its monitoring procedures they might use, or by making modifications to its monitoring program to better facilitate external parties' work" (50).

SOX initially required the external auditor to evaluate management's assessment of internal control strength, in addition to the auditor's own assessment. ${ }^{6}$ ICM technology can facilitate the documentation of the results of management's monitoring and assessment activities. For example, this technology represents an audit trail of management's monitoring efforts. Such audit trail attributes include the provision of a central repository for comprehensive and exhaustive documentation of internal controls and related testing. In turn, timely client-prepared reports, required by auditors, can also be provided.

\footnotetext{
${ }^{6}$ Auditors were subject to PCAOB Standard No. 2 during the time period studied.
} 
During the time period studied, the need for audit efficiency and managing the costs of compliance represented some of the most contentious attributes of the debate surrounding SOX internal control requirements. Notable is the large increase in audit fees experienced by publicly traded firms. For example, Raghunandan and Rama (2006) study a group of 660 manufacturing firms and find a median increase in audit fees of 128 percent from years 2003 to 2004. The authors emphasized the impact of the additional efforts to comply with the expanded reporting and auditing requirements of SOX. They also noted an increase in the impact of firm complexity and risk on external audit fees. Consistent with the COSO framework, effective monitoring strategies provide evidence about an organization's ability to manage or mitigate organizational risks (COSO 2009a).

To the extent that ICM technology can effectively aid the efficiency of the external assurance process and evidence collection, we should also see corresponding alleviations of the increases in audit effort brought on during the SOX time period studied, leading to greater audit efficiency and audit costs containment, as next posited:

H2: Firms implementing ICM technology will exhibit smaller increases in audit fees subsequent to ICM technology implementation.

Despite the consistent emphasis on audit efficiency embedded in the COSO's conceptual description of ICM activities, it remains an empirical question as to whether such technology initiatives would actually yield assurance cost-savings. Although prior studies used field-based approaches to describe the external auditors' perceptions about the use of audit-related IT (Fischer 1996; Janvrin et al. 2008), to our knowledge, ours is one of the first study to provide archival evidence regarding external audit cost outcomes from the client's implementation of assurance-related technology.

\section{Audit Timeliness}


We also ask whether ICM technology impacts assurance outcomes by considering the timeliness of audit reports (i.e., days from fiscal year-end to external audit report date). During the time period under study, firms faced burgeoning audit delays as a result of increased audit requirements. Ettredge et al. (2006) document significant increases in audit delays due to the Section 404 internal control requirements of SOX. They assert that audit delays are attributable not only to the additional assurance requirements of the external auditor, but also to Section 404 preparations required of the audit client. These preparations include documentation, assessments, and improvements to various internal controls over financial reporting. To the extent these preparations are incomplete, the auditor can expect increases in the extent of audit effort necessary in order to meet the expanded audit requirements of SOX, which in turn can lengthen audit delays (Knechel and Payne 2001; Ettredge et. al 2006). Features of ICM technology that purport to impact audit engagement timeliness include, but are not limited to, maintaining comprehensive documentation, managing disparate reporting systems, monitoring and automating business process workflows, providing timely client-prepared reports required by auditors, and generating audit trails. Therefore, ICM technology should enhance effective monitoring activities that promote timely audit responses or mitigate the increased audit delays associated with expanded compliance requirements attributed to section 404. Hence, we predict the following hypothesis:

H3: Firms implementing ICM technology will exhibit smaller increases in audit delays subsequent to ICM technology implementation.

In contrast to the above hypothesis, Behn et al. (2006) find that audit partners do not systematically view technology aids as key determinants of constraints on audit delays (lags). This view is in contrast to the direct benefits touted by ICM technology initiatives. Rather, Behn et al. (2006) find that audit partners associate changes in personnel resources, professional mindsets, auditor skill-sets, and scheduling as key determinants of audit delays 
(lags). Thus, it is unclear whether such tools will result in significant associations with audit report delays. However, to the extent that ICM technology implementations offset the laborintensive process of SOX compliance, we should see an indirect alleviation of impediments resulting from personnel resources, required auditor skills, and scheduling flexibility, thereby mitigating audit delays.

\section{The Strategic Nature of ICM Technology}

Prior research has shown that the benefits of IT are conditioned upon the strategic nature of the investment on the firm (Chatterjee et al. 2001; Dehning et al. 2003). Dehning et al. (2003) classify the IT strategic role into three categories:

1. Automate: Replace human labor by automating business processes with virtually no IT-driven transformation efforts.

2. Informate: Provide new information to empower management, employees, and customers for better decision-making.

3. Transform: Radically alter ways of doing business by redefining business capabilities, business processes, and relationships.

Based on these IT strategic role definitions, we classify ICM technology implementations into two strategic role categories: Compliance and Transformative (see the Appendix for examples of announcements of ICM technology implementations related to transformative and compliance purposes). We define a Compliance strategic role as one where the firm implements ICM technology focused on simply complying with SOX requirements, thus reducing compliance complexity as well as compliance cost. The main goal of this implementation is to reduce time and cost of SOX compliance as well as to meet SOX deadlines. Firms utilize ICM technology with the main focus of standardizing the internal control monitoring process, including documentation, monitoring, and testing. In addition, a compliance strategic role aims to streamline only selected and specific business procedures and targets only certain aspects of internal control, such as policy management, record of segregation of duties, documentation, and document workflow. 
In contrast, ICM technology implementations with a Transformative strategic role have a greater purpose beyond simply complying with SOX requirements. In this category, firms implement ICM technology to integrate their monitoring activities into overall enterprise-wide risk and compliance management initiatives, in addition to the goal of SOX compliance. This role transforms how the firm manages internal control and risk. Firms embed the ICM technology into the companies' overall information systems.

In contrasting transformative vs. compliance-oriented ICM technology, we note that the former is more consistent with the concept of "ongoing monitoring" activities vs. "separate evaluations." COSO identifies ongoing monitoring activities as those that are embedded or ingrained into the organization's enterprise-wide risk management system, whereby internal controls are potentially monitored on a real-time basis (COSO 2009b). As such, the original COSO framework asserts that ongoing monitoring procedures should be more effective than monitoring activities that operate in isolation and are not ingrained in the routine operations of the firm (COSO 1992). While firms implement technology in order to yield positive benefits from either Compliance or Transformative IT strategic initiatives, we expect Transformative ICM technology to yield greater benefits:

H4: ICM technology transformative implementations will exhibit greater impacts on assurance outcomes than ICM technology compliance implementations.

\section{Sample Selection}

\section{IV.RESEARCH DESIGN}

To identify firms that implemented ICM technology, we collect announcements of firms implementing technology that is explicitly targeted at monitoring and assuring compliance with SOX internal control requirements through public sources, such as Lexis-

Nexis news and PR newswire. Our search uses keywords searches such as "SOX information technology," "SOX software," and "Sarbanes-Oxley solution," among others. Our searches identified 152 firm announcements of the implementation of specific SOX-related ICM 
technology from 2003-2006. We deleted 13 observations from the sample, due to their absence in the Audit Analytics or Compustat databases. This procedure left 139 observations of firms announcing SOX-related ICM technology initiatives over a four-year period (20032006). ${ }^{7}$

Consistent with Doyle et al. (2007), we use a population-based control sample, rather than a matched-pair design, to avoid choice-based sample bias. ${ }^{8}$ In constructing our control firm group, we first compiled all of the firms listed in Audit Analytics SOX 404 Internal Controls database during the same years in which we found SOX-related ICM technology announcements (2003-2006). We then required that the control firms issued a SOX 404 internal control report corresponding to year $\mathrm{t}+1$ (our test year) and had corresponding information in the Compustat database. ${ }^{9}$ This process resulted in 14,654 control firm-year observations. Table 1 provides a summary of the sample distribution based upon year of SOX-related ICM technology observations and industry distribution by two-digit SIC code. As shown in panel A of Table 1, the largest concentration of ICM technology firms is in 2005 ( $n=61$ ), with the majority of the firms implementing "compliance-oriented" ICM technology $(\mathrm{n}=47)$. Panel B shows that industry concentration may not be a problem. With the exception of SIC 36 - Electronic \& Other Electrical Equip. \& Components Except Computer Equipment (18 firms, 15 of which are "compliance-oriented”) and SIC 73 - Business Services (14 firms, 13 of which are "compliance-oriented"), no other industries are overly represented. Untabulated tests suggest that industry effects do not affect our multivariate inferences.

\section{[INSERT TABLE 1 HERE]}

\footnotetext{
${ }^{7}$ In an effort not to lose observations due to missing data, every time the value of any variable was missing in compustat for our treatment firms, we replace the missing value with the sample mean. Three treatment firms were impacted by these changes with no impact on the results.

${ }^{8}$ As discussed in the sensitivity tests section, we also re-estimate our models using a matched pair design and find that our inferences remain the same.

${ }^{9}$ We implemented this requirement to maximize the number of firms that issued a Section 404 report, particularly in the early years of our sample period. For accelerated files (large firms for the most part), compliance with section 404 came into effect in November $15^{\text {th }} 2004$. However, for non-accelerated files, the compliance date was December $15^{\text {th }} 2007$.
} 


\section{Model Specifications}

\section{Internal Assurance Benefits}

To test H1, we construct a material control weakness regression model following Doyle et al. (2007). Our first OLS regression model is as follows:

$$
\begin{aligned}
\text { Weaknesses }_{\mathrm{t}+1}= & f\left(\beta_{0}+\beta_{1} \text { SOX ICM }_{\mathrm{t}}+\beta_{2} \text { Assets }_{\mathrm{t}+1}+\beta_{3} \text { Firm Age }_{\mathrm{t}+1}+\beta_{4} \text { Los }_{\mathrm{t}+1}+\right. \\
& \beta_{5} \text { BankruptcyRisk }_{\mathrm{t}+1}+\beta_{6} \text { Segments }_{\mathrm{t}+1}+\beta_{7} \text { ForeignTransactions }_{\mathrm{t}+1}+ \\
& \beta_{8} \text { Merger }_{\mathrm{t}+1}+\beta_{9} \text { ExtremeSalesGrowth }_{\mathrm{t}+1}+\beta_{10} \text { Restructuring }_{\mathrm{t}+1}+ \\
& \left.\beta_{11} \text { Trend }_{\mathrm{t}+1}+\text { error term }\right) .
\end{aligned}
$$

We define Weaknesses as the number of material weaknesses reported in a firm's 404 reports.

Since IT implementations typically exhibit lags prior to producing the expected benefits

(Barua and Mukhopadhyay 2000), we consider whether the material control weaknesses

occur in the year subsequent $(\mathrm{t}+1)$ to the announcement of SOX-related ICM technology $(\mathrm{t})$

(hereafter SOX ICM).

Our primary test variable (SOXICM) is an indicator variable specified as 1 if the firm announced implementation of SOX-related ICM technology in year $\mathrm{t}$ and 0 otherwise. In examining whether the strategic role of the ICM technology impacts the internal control systems (H4), we bifurcate the SOX ICM variable into two separate indicator variables: SOX ICM Transform and SOX ICM Comply, which are coded 1 if the firm announced implementation of SOX-related ICM technology that are characterized as having a transformative and compliance role respectively and 0 otherwise. ${ }^{10,11}$ Given the stated hypotheses, we expect a negative sign on the SOX ICM coefficients. This would imply that the implementation of ICM technology reduces the likelihood of material weaknesses.

\footnotetext{
${ }^{10}$ Following Dehning et al. (2003), two authors of this study independently coded the ICM technology implementations into comply and transform by carefully scrutinizing press release announcements with a 95 percent concordance. Any differences were resolved in face-to-face discussions.

${ }^{11}$ In untabulated analysis, we find that SOX ICM Comply firms do not differ from SOX ICM Transform firms. We compare these two types of firms along the same dimensions reported in Table 3.
} 
We control for firm size (Assets) and age (Firm Age) by using the natural logarithm of total assets and the number of years the firm has been trading in a stock exchange, respectively. We control for financial health and risk level by including two variables: an indicator variable coded 1 if the firm reports negative earnings and 0 otherwise (Loss), as well as the Altman's bankruptcy score (Bankruptcy Risk). In addition, we control for the complexity of the firm's operations by including the number of the firm's geographic segments (Segments), and an indicator variable coded 1 if the firm reports foreign income or losses and 0 (Foreign Transactions). We control for rapid growth and restructuring activity by including three variables: an indicator variable coded 1 if the firm engages in mergers and acquisitions and 0 otherwise (Merger), an indicator variable coded 1 if the firm's industryadjusted sales growth is in the top quintile of the sample and 0 otherwise (Extreme Sales Growth), and pre-tax restructuring charge scaled by market value of equity (Restructuring). Finally, we include a trend (Trend) variable capturing overall macro-economic effects (e.g., Adut et al. 2003; Brazel and Dang 2008). As stated above, with the exception of Trend, the control variables and their expected directional effects are modeled after Doyle et al. (2007). ${ }^{12}$ We present more detailed definitions of the control variables in equation (1) in Table 2.

\section{[INSERT TABLE 2 HERE]}

\section{External Assurance Outcomes}

To test $\mathrm{H} 2$, we examine whether the observed large increases in audit fees during the Post-SOX time period were constrained by the implementation of SOX-related ICM technology. We adapt the audit fee model of Raghunandan and Rama (2006) for our audit fee tests using the following OLS change model:

\footnotetext{
${ }^{12}$ Doyle et al. (2007) also control for the overall corporate governance environment but do not find any significant associations between their governance proxy and material weaknesses.
} 
$\Delta$ Audit Fees $_{\mathrm{t}+1}=f\left(\lambda_{0}+\lambda_{1} S O X\right.$ ICM $_{\mathrm{t}}+\lambda_{2} \Delta$ Asset $_{\mathrm{t}+1}+\lambda_{3}$ UReceivablesandInventory $\mathrm{H}_{\mathrm{t}+1}+$

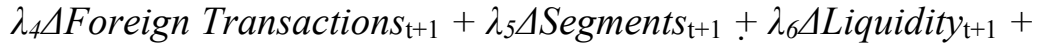

$$
\begin{aligned}
& \lambda_{7} \Delta \text { Leverage }_{\mathrm{t}+1}+\lambda_{8} \Delta R O A_{\mathrm{t}+1}+\lambda_{9} \Delta \text { GoingConcern }_{\mathrm{t}+1}+\lambda_{10} \Delta B \text { Big }_{\mathrm{t}+1}+ \\
& \lambda_{11} \Delta \text { Weakness }_{\mathrm{t}+1}+\lambda_{12} \text { Trend }_{\mathrm{t}+1}+\text { error term). }
\end{aligned}
$$

Audit Fees represents the total audit fees incurred by the firm as reported in Audit Analytics. Our tests require estimating and comparing the changes in audit fees for firms implementing SOX-related ICM technology compared to our control firms. Thus, $\triangle$ Audit Fees $_{\mathrm{t}+1}$ measures the percentage change in audit fees from the year of implementation to the year after implementation. We expect a negative sign on the SOX ICM coefficients. Given the pervasive increases in audit fees experienced by our sample, a negative coefficient would imply that the implementation of ICM technology is associated with a reduction in subsequent audit fee increases. Assets, Foreign Transactions, Segments and Trend are defined as in the previous model. We define Receivables and Inventory and Liquidity as the ratio of the sum of net account receivables and inventory to total assets and the ratio of total current assets to total current liabilities, respectively. We also control for Leverage and return on assets (ROA) defined as the ratio of total debt (net income) to total assets. We include indicator variables coded 1 if: the auditor issues a going concern opinion (Going Concern), the auditor is a big $\mathrm{N}$ auditor (Big 4), and the firm reported a material control weakness (Weakness); all such variables are coded 0 otherwise. Consistent with the measurement of the dependent variable, we measure all continuous (indicator) independent variables in equation (2) in percent changes (changes). We draw directional expectations consistent with generally accepted audit fee research (e.g., Raghunandan and Rama 2006). Table 2 presents detailed definitions of the control variables in equation (2).

To test H3, we examine whether ICM technology enhances assurance efforts as proxied by constraints on audit delays in the Post-SOX environment. We adapt the audit delay model of Ettredge et al. (2006) for our tests. Our third OLS model is as follows: 
$\Delta$ Audit Delays $_{\mathrm{t}+1}=f\left(\gamma_{0}+\gamma_{1}\right.$ SOX ICM $_{\mathrm{t}}+\gamma_{2} \Delta$ Assets $_{\mathrm{t}+1}+\gamma_{3} \Delta$ ROA $_{\mathrm{t}+1}+\gamma_{4} \Delta_{\text {Leverage }_{\mathrm{t}+1}}+$

$$
\begin{aligned}
& \gamma_{5} \Delta \text { Going Concern }_{\mathrm{t}+1}+\gamma_{6} \Delta \text { Restructuring }_{\mathrm{t}+1}+\gamma_{7} \Delta \text { Segments }+\gamma_{8} \Delta \text { Loss }_{\mathrm{t}+1}+ \\
& \gamma_{9} \Delta \text { Restatement }_{\mathrm{t}+1}+\gamma_{10} \Delta \text { Audit Fees }+\gamma_{11} \Delta \text { Weakness }+ \\
& \gamma_{12} \Delta \text { AuditorChange }+\gamma_{13} \text { Trend }+ \text { error term). }
\end{aligned}
$$

Audit Delays represents the number of days between the audit report date and the fiscal year end (Ettredge et al. 2006). Our tests require estimating and comparing the changes in audit delays of firms implementing ICM technology (SOX ICM) compared to our control firms. Hence, $\Delta$ Audit Delays ${ }_{\mathrm{t}+1}$ measures the percentage change in audit report delays from the year of implementation to the year after implementation. As with audit fees, we expect a negative sign on the SOX ICM coefficients, which would suggest that the implementation of ICM technology is associated with timelier subsequent audit reports. With the exception of Auditor Change (Restatement), defined as an indicator variable coded 1 if the firm changes auditors (restates earnings) and 0 otherwise; all control variables are as defined earlier. Consistent with the dependent variable, we measure all continuous (indicator) independent variables in equation (3) in percent changes (changes). We draw directional expectations consistent with generally accepted audit fee research (e.g., Ettredge et al. 2006). Table 2 presents more detailed definitions of the control variables in equation (3).

\section{Extended Models}

The models specified in equations (1), (2), and (3) represent our baseline models and are largely constructed following prior literature (i.e., Doyle et al. 2007; Ettredge et al. 2006; Raghunandan and Rama 2006). In an effort to test the robustness of our results, we extend these baseline models in three ways. First, while the independent variables in each of our equations largely overlap each other, non-overlapping variables (e.g., Restatement) may affect other assurance outcomes such as material weaknesses or audit fees. Hence, to ascertain that our tests are robust to additional potentially important variables, we extend our models to capture these factors. 
Secondly, it is possible that our ICM technology (SOX ICM) variable is correlated with overall financial reporting quality. Failing to control for this possibility could yield biased estimates. ${ }^{13}$ We consider this possibility and control for financial reporting quality using the absolute level of performance-matched discretionary accruals (Absolute Accruals). Higher levels of Absolute Accruals (estimated following Kothari et al. 2005) are likely to be associated with lower financial reporting quality (Ashbaugh-Skaife et al. 2008). ${ }^{14}$

Third, firms that implement ICM technology may "self-select" into this group, and those variables that predict the decision to implement ICM technology might also affect the dependent variables examined in our analysis. This potential condition presents an omitted variable problem (Heckman 1979). In addition, some of our treatment firms may have chosen to implement ICM technology while taking steps to increase the coordination of their internal and external assurance efforts. This potential condition presents a simultaneity issue.

Assuming either of these cases, our estimates could be biased and inconsistent. To control for these issues, we follow the Heckman (1979) two-step procedure, where we first model the decision to implement ICM technology (SOX ICM) with the following probit model:

$\operatorname{Pr}\left(\mathrm{SOX} \mathrm{ICM}_{\mathrm{t}}\right)=\mathrm{f}\left(\zeta_{0}+\zeta_{1}\right.$ Assets $_{\mathrm{t}-1}+\zeta_{2}$ ROA $_{\mathrm{t}-1}+\zeta_{3}$ BankruptcyRisk $_{\mathrm{t}-1}+\zeta_{4}$ Leverage $_{\mathrm{t}-1}+\zeta_{5} I T$

$$
\text { Intensity }_{\mathrm{t}-1}+\zeta_{6} \text { Absolute Accruals }_{\mathrm{t}-1}+\zeta_{7} \text { Audit Fees }_{\mathrm{t}-1}+\text { error term) }
$$

With the exception of IT Intensity, defined as the yearly industry (measured at the two-SIC code) median of IT spending scaled by total assets, all other variables are as defined previously (please note that our IT spending data stops in 2005). Equation (4) is estimated using 12,161 firm-year observations with complete data (125 of which are ICM technology firms). We find a positive association ( $p<0.10$ or better, one-tail test) between the decision

\footnotetext{
${ }^{13}$ We thank an anonymous reviewer for highlighting this possibility.

${ }^{14}$ We also consider an additional proxy for financial reporting quality: the permanence of cash flows from operations (CFO Permanence) (Guay and Hartford 2000), defined as the difference between the average of cash flow from operations in years $t$ and $t+1$ and average of cash flow from operations in years $t-1$ and $t-2$. However, CFO Permanence was insignificant in all of our models, so we do not tabulate these results for parsimony.
} 
to implement ICM technology (SOX ICM) and BankruptcyRisk, Leverage and Audit Fees. ${ }^{15}$

These results suggest that prior firm performance and audit assurance levels have an impact on the decision to implement ICM technology. Using the estimation results from equation (4), we then construct the inverse Mills ratio (Heckman) and use it as an additional explanatory variable in our extended tests.

\section{RESULTS}

\section{Univariate Analyses}

Table 3 presents the descriptive statistics (all measured one year after implementation) of our sample split by ICM technology (SOX ICM) firms and Control firms. ${ }^{16}$ The table reveals that significant differences between SOX ICM firms and control firms (at the 5 percent level or better) are largely related to size and performance. ${ }^{17}$ The mean of Assets (Firm Age) for SOX ICM firms is 15.27 billion (29.35 years), which is significantly larger than for control firms (7.65 billion and 18.6 years, respectively). Additionally, SOX ICM firms have significantly more Segments (6.11) than control firms (4.68). Collectively, these differences suggest that ICM technology firms are older and more stable.

\section{[INSERT TABLE 3 HERE]}

Similarly, SOX ICM firms exhibit better performance relative to control firms. For instance, compared to control firms, SOX ICM firms have significantly higher ROA (0.040 vs. 0.001), report Losses less frequently (0.101 vs. 0.219), and have lower propensities of Extreme Sales Growth (0.050 vs. 0.168). SOX ICM firms are also more likely to engage a Big 4 auditor (0.971 vs. 0.828$)$, face Auditor Changes less often (0.014 vs. 0.058$)$, pay higher audit fees (4.723 million vs. 2.460 million), and are more likely to engage in Merger

\footnotetext{
${ }^{15}$ In an alternate specification of equation (4), we also use prior weaknesses as a predictor of ICM technology (SOX ICM) implementation. We find similar results but lose a large number of treatment observations. To maximize our observations we utilize Audit Fees to capture additional risk factors and assurance strategies in the lagged period.

${ }^{16}$ We also contrasted all of these variables at year $\mathrm{t}$ (implementation year) finding similar patterns.

${ }^{17}$ Test of medians yield similar inferences.
} 
activities (0.568 vs. 0.380$)$. SOX ICM firms and control firms do not differ with respect to other aspects of financial reporting quality (e.g., Restructuring, Restatement, and Absolute Accruals). Overall, our descriptive analysis highlights the importance of controlling for firm characteristics that may impact each of the dependent variables we examine. ${ }^{18}$

Table 4 provides univariate tests of differences among the SOX ICM firms and control firms with respect to the internal and external assurance outcomes for the years before, during, and after ICM technology implementation. Panel A displays the number of firms reporting material weaknesses. In year t-1, SOX ICM firms have a significantly larger number of material weaknesses than control firms (0.649 vs. 0.322$)$. However, SOX ICM firms show significantly fewer occurrences of reported material weaknesses during the period after implementation compared to the control group of firms $(p<0.05)$. While this analysis is consistent with our expectations (i.e., ICM technology implementation mitigates the likelihood of reporting a material control weakness), the larger number of occurrences of reported material weaknesses for SOX ICM firms in the year prior to implementation might have instigated the decision to implement ICM technology. ${ }^{19}$ As discussed in the Extended Models heading within the research design section, it is possible that lagged audit assurance efforts are associated with the decision to implement ICM technology. We consider this possibility by controlling for self-section through the Heckman variable.

Panel B in Table 4 reports the mean increases in audit fees for the SOX ICM firms decelerates significantly $(p<0.05)$ from the year prior to implementation $(76.2$ percent increase) to the year of (48.1 percent increase) and subsequent year (24.0 percent increase).

\footnotetext{
${ }^{18}$ We estimate (but not tabulate for parsimony) correlations amongst all the variables to find that, as predicted, the $S O X I C M$ variable is negatively related to subsequent material weaknesses, audit fee increases and audit delay increases $(p<0.05$ or better). We also find the theoretically correlations levels between other control variables. Additionally, we estimated VIFs in all of our models and found that these do not exceed 2.0, suggesting that multicollinearity is not a problem.

${ }_{19}$ As noted in Panel A (and to a lesser extend in panels B and C), we lose approximately 60\% of our sample firms in year t-1, which may affect the analysis. The large loss of observations for both treatment and control firms is due to the fact that many firms do not provide a 404 report in year t- 1 or $\mathrm{t}$. As stated above, this is due to the 404 requirement not coming to effect until November $15^{\text {th }} 2004$ for accelerated filers and December $15^{\text {th }}$ 2007 for non-accelerated filers. As a sensitivity test, we estimated all of our models after excluding all of the firms in the pre- 404 requirement (i.e., 2003) finding similar results.
} 
There is a visible deceleration of audit fee increases for control firms, but the differences are not as dramatic. When we contrast SOX ICM firms and control firms, we find that audit fee increases differ between the two types of firms only in the post-period $(p<0.01)$. The pattern of differences is consistent with H2, which proposes that SOX ICM bolsters audit efficiency as proxied by constraints on increasing audit fees.

\section{[INSERT TABLE 4 HERE]}

Panel $\mathrm{C}$ in Table 4 reports the mean audit report delays increase. We observe similar patterns to those reported for audit fee increases. For the SOX ICM firms, the mean increase in audit delays decreases significantly $(p<0.05)$ from the year prior to implementation $(35.1$ percent increase) to the year of (17 percent increase) and subsequent year (5.5 percent increase). Control firms experience a decrease in audit delay increases, but the decrease is not as large. We find that audit delay increases differ between SOX ICM firms and control firms only in the post-implementation year $(p<0.05)$.

Overall, the univariate tests suggest that, with the exception of control weaknesses, SOX ICM firms and control firms do not significantly differ from one another prior to the period of ICM technology implementation with respect to audit fee increases or audit delay increases. However, for each of the variables considered, SOX ICM firms display stronger internal (control weaknesses) and external (audit fee and audit delay efficiencies) assurance outcomes in the year after the ICM Technology.

\section{Multivariate Analyses}

Table 5 reports the results of the associations between SOX ICM technology and the likelihood of a reported material weakness in the year after implementation. Columns (1)(3) report the results aggregating all SOX ICM technology into one bucket (SOX ICM). As one moves from columns (1) to (3), the model increases in the amount of control variables included. To illustrate, the least restrictive model (column 1) is adapted from Doyle et al. 
(2007) and represents our baseline model, whereas the most restrictive model (column 3)

includes all variables identified in Doyle et al. (2007) plus variables posited to affect the reporting of control weaknesses (e.g., restatements) and a correction for self-selection (Heckman) ${ }^{20}$ The models reported in columns $(4)-(6)$ replicate the logic behind those in columns (1) - (3), with the exception that instead of aggregating ICM technology into one bucket, we use two variables (SOX ICM Transform and SOX ICM Comply) that capture the two different strategic scope of ICM technology.

Consistent with H1, we find a significantly negative association between SOX ICM and the number of weaknesses reported in the subsequent year (coefficient ranges from 0.100 to $-0.161, p<0.05$ or better). This result suggests that firms implementing ICM technology reap the internal assurance benefits of stronger control systems. ${ }^{21} \mathrm{We}$ also find that the strategic type of ICM technology (i.e., SOX ICM Transform and SOX ICM Comply) is not incrementally associated with the likelihood of reporting a control weakness (i.e., the coefficients of SOX ICM Transform and SOX ICM Comply do not differ from one another based on Wald tests). This result fails to support our expectation in H4.

\section{[INSERT TABLE 5 HERE]}

Similar to Doyle et al. (2007), we also find negative (positive) associations between material weaknesses and Assets and Bankruptcy Risk (Segments, Foreign Transactions, Restructurings, and in some cases, Mergers). ${ }^{22}$ We do not find any associations between

\footnotetext{
${ }^{20}$ As we discuss more fully in the sensitivity tests section, only in approximately $12 \%$ of the firm-year observations is at least one weakness reported; a percentage consistent with Doyle et al. (2007). We examine the potential bias introduced by the large proportion of "zeroes" in the dependent variable using various econometric techniques including the estimation of truncated and Tobit models. As discussed later, these alternate ways of testing our prediction yields similar results. We also modeled the likelihood of having a weakness using a probit model and find similar results.

${ }^{21}$ To complement this result, for every SOX ICM technology firm that reported at least one material weakness, we searched for evidence of remediation in the subsequent year. We find that more than $60 \%$ of the SOX ICM treatment firms remediated the weaknesses reported. We contrast these results against a sample of 100 similarly sized control firms and find that out of the firms that reported a weakness, 44\% remediated their weaknesses in the subsequent year. We find that the material weaknesses remediated for the SOX ICM treatment sample is significantly greater than the material weaknesses remediated for the control sample, which is generally consistent with $\mathrm{H} 1$.

${ }^{22}$ We include Trend in every model to control for overall economic factors (Brazel and Dang 2008; Adut et al. 2003). The negative and significant coefficient in Trend implies an increasing (at a decreasing rate) trend in the
} 
material weaknesses and Firm Age and Extreme Sales Growth. Columns (2) and (5) consider other variables that may impact the likelihood of reporting a material weakness. We find that Restatements, Going Concern and Audit Fees are positively associated with the likelihood of reporting a material weakness. We also consider Absolute Accruals, finding a positive association with the likelihood of reporting a material weakness, a result consistent with Ashbaugh-Skaife et al. (2008). In the models shown in columns (3) and (6), we control for potential self-selection bias through the Heckman variable, finding that, while significant (suggesting the presence of self-selection), our primary results remain unchanged. Audit fees and our proxy for financial reporting quality variables (Absolute Accruals) are not in the models reported in columns (3) and (6) because we use lagged versions of these variables in the estimation of the Heckman variable. ${ }^{23}$

Tables 6 and 7 report the associations between our SOX ICM variables and our external assurance outcomes, namely audit fees and audit delays. Table 6 presents the results using the audit fee percent change as the dependent variable. Consistent with $\mathrm{H} 2$, we find a significantly negative association between SOX ICM and the extent of increases in audit fees (coefficient ranges from -0.071 and $-0.151, p<0.05$ ). The coefficient on SOXICM of -0.151 implies that firms implementing ICM technology face audit fee increases that are approximately 15.1 percent lower than those faced by control firms. When we examine whether ICM technology strategic type have any impact on audit fees (columns 4-6), contrary to our expectations in H4, we find that the coefficient of SOX ICM Transform does not differ from the SOX ICM Comply coefficient, suggesting that ICM technology type does not

reporting of material control weaknesses. This result is consistent with the descriptive statistics reported in Table 3 (i.e., the reporting material control weakness, and each of the other two dependent variables, increases at a decreasing rate from years $\mathrm{t}-1$ to year $\mathrm{t}+1$ ). We also estimate our models using year fixed-effects and our inferences remain unchanged. In addition, we estimate our models on a year-by-year basis and generally find similar results.

${ }^{23}$ Lennox and Francis (2008) emphasize the importance of ascertaining that the insertion of the inverse Mills ratio (Heckman) in the main model does not cause unduly multicollinearity as a result of violations of "exclusion restrictions" (see Lennox and Francis for more details on this). We find that VIFs after including Heckman in our main models do not exceed 1.50, suggesting that Heckman serves as an important control for self-selection without introducing bias in our analysis. 
incrementally influence audit fee increases. The control variables are generally consistent with those reported by Raghunandan and Rama (2006); Assets, Receivables and Inventory, Segments, Leverage, Big 4 and Weaknesses (Liquidity) are positively (negatively) associated with audit fee percent increases. We do not find an association between audit fee percent increases and Foreign Transactions, ROA and Going Concern. On the other hand, out of the additional control variables we added to the model (columns 2 and 4), we find that Restatement and Bankruptcy Risk are associated with audit fee percent increases. Also, the significant coefficient on the Heckman variable implies the presence of self-selection. Importantly, the inclusion of these variables does not alter our main results.

\section{[INSERT TABLE 6 HERE]}

Table 7 presents the results using audit delay percent increases as the dependent variable. Consistent with $\mathrm{H} 3$, we find a significantly negative association between SOX ICM and the extent of audit delay increases (coefficient ranges between -0.058 and $-0.063, p$ $<0.05$ ). Using the baseline model (column 1) coefficient of -0.06 implies that firms implementing ICM technology face audit delay increases that are approximately 6 percent lower when compared to those audit delay increases faced by control firms. When we examine whether ICM technology type have any impact on audit delay increases, we find (untabulated) that the coefficient of SOX ICM Transform does differ from the SOX ICM Comply coefficient, supporting H4 for audit delays. In fact, the SOX ICM transform coefficient is the only negative and significant coefficient (coefficient rages between -0.133 and -0.149), implying that firms implementing ICM technology with a transformative nature face audit delay increases that are approximately 13.4 percent lower using the base model in column (4) than those faced by control firms. The control variables are generally consistent with those reported by Ettredge et al. (2006); Restatements, Audit Fees and Weaknesses (Assets) are positively (negatively) associated with audit delay increases. We find no (marginal) associations between audit fee increases and ROA, Leverage, Restructuring, 
Segments and Loss (Going Concern). We do find significant associations between the additional variables added to the model (Firm Age, Bankruptcy Risk, and Absolute Accruals) and audit delay increases. Finally, the positive and significant coefficient on Heckman suggests the presence of self-selection.

[INSERT TABLE 7 HERE]

Overall, our main multivariate results are consistent with the notion that ICM technology implementations yield benefits realized in both internal (i.e., lower likelihood of material weaknesses) and external (i.e., lower audit fee increases and lower audit delay increases) assurance outcomes. We find limited evidence (only in the case of audit delays) that the strategic role of the ICM technology made a significant difference.

\section{Robustness Tests}

\section{Alternate Control Group}

Our research design includes all firms in Audit Analytics that provide a Section 404 report in year $\mathrm{t}+1$, and did not announce an ICM technology implementation, as control firms. A potential disadvantage of this procedure is that we are not comparing firms of similar characteristics. As described in Table 3, ICM technology firms are different compared to the population in various characteristics like size and complexity of operations. Accordingly, as an additional robustness check, we construct a matched-pair control group. For every SOX ICM firm, we identify a match firm based on size (total assets), industry affiliation (at 2-digit SIC code), auditor (Big 4), and provision of a Section 404 report. We then re-estimate our main models. The (untabulated) regressions yield virtually identical results as those reported.

\section{Management Changes and ICM Technology Implementation}


Krishnan et al. (2008) document a positive association between the presence of a new CEO and the costs of complying with Section 404, implying that new CEOs can be viewed as "agents of change." Hence, it is possible that our results are influenced by CEO changes. To rule out this possibility, we determine if a CEO change occurred during the two-year period leading up to the IT implementation decision. To mitigate costly hand collection for our entire control group, we take advantage of our match-pair control group and identify CEO changes (in the current or prior two years) for each matched pair. Using this additional data, we also include $N e w C E O$, a variable that captures the impact a new CEO might have on the underlying improvement of the internal control environment and on the decision to implement ICM technology. Inclusion of the additional New CEO variable in our models does not change our primary results.

\section{Potential Simultaneity Between Dependent Variables}

It is possible that weaknesses, audit fees, and audit delays are simultaneously determined. Our primary tests, control for this possibility by including audit fees (weaknesses) in the weaknesses and audit delays (audit fees and audit delays) models. As a further sensitivity test, we estimate our models under a two-stage (and three-stage) leastsquares framework to allow each of these variables to be simultaneously determined. Consistent with our tabulated tests, we continue to find negative and significant associations $(p<0.05)$ between the SOX ICM technology variables and each of the dependent variables.

\section{Potential Econometric Issues Related to Control Weakness Tests}

As discussed in our research design section, we estimate OLS models when we examine the association between ICM technology and the number of material control weaknesses reported. As documented in prior research (Doyle et al. 2007) and corroborated in our analysis, less than 15 percent of firm-year observations are associated with a material 
control weakness. To mitigate the bias this low frequency may induce on our results, we conduct several tests. First, we re-estimate the models after excluding all "zero" observations (that is, we run a truncated regression), and find virtually the same result.

We also estimate a generalized Tobit model that incorporates the reporting of material weaknesses into two simultaneous steps: (1) the auditor's decision to establish that at least one material weakness exists (a first-stage probit model) and (2) the number of material weaknesses identified (a second-stage OLS model). The second stage OLS model conditions the number of material weaknesses on the decision to report at least one material weakness (first-stage model). This alternative test yields virtually the same results (i.e., SOX ICM is negatively associated with the number of material weaknesses).

\section{Limitations}

There are several limitations that could condition our ability to generalize results. As common among archival assurance and governance studies, we cannot rule out possibilities of omitted correlated variables. Specifically, it is possible that ICM technology (SOXICM) is correlated with other decisions or efforts within firms that ultimately drive the assurance benefits documented in this study. For example, it is possible that our ICM technology firms were generally more aggressive in addressing the Section 404 requirements, through early efforts to curb control weaknesses or coordinate the internal and external assurance efforts. Although our design of the models and robustness tests are aimed at alleviating the above conditions, we cannot conclusively rule them out.

As mentioned in the description of our extended models, our sample is constrained to disclosures of SOX-related ICM technology implementations. However, some firms may have chosen not to disclose their SOX ICM technology implementations. To the extent that the control sample includes firms that adopted SOX-related ICM technology, this would bias against finding significant results. Alternatively, those firms choosing to "announce" their IT 
implementations could also be subject to additional pressures to reap the benefits of their ICM technology. Although prior IT research finds positive reaction to announcements of IT investments (Dehning et al. 2003), there is no evidence of guaranteed IT benefits resulting from "announcements." Nevertheless, our findings are subject to this possible influence.

Some of the benefits of ICM technology may also take an extended period of time to realize. Given the short sample period of time used in this study to measure the benefits, due to the recency of the SOX-related ICM technology, future research should be undertaken to ensure that the full measure of benefits are included to assess the impact of ICM technology. We also recognize that our study only evaluates the potential benefits of SOX-related ICM technology and not the costs. Users of ICM technology should also consider the costs of such initiatives when attempting to measure the ultimate value of ICM technology. Future research should consider the challenges of measuring indirect costs (such as constraints on productivity or limits to user acceptance, among others) of ICM technology.

\section{SUMMARY AND CONCLUSION}

The Sarbanes Oxley Act of 2002 has led firms to increase their level of resources committed to effective internal control monitoring. The current study takes an approach of measuring potential outcomes of internal control monitoring practices by considering explicit benefits associated with monitoring technology as represented by internal assurance outcomes (i.e., internal control system strength) and external assurance outcomes (i.e., audit efficiency and audit timeliness). Collectively, our study supports the benefit-related assertions embedded within the conceptual application of effective internal control monitoring practices.

Our study enhances current research and practice on numerous fronts. For the AIS researcher, our findings stress the importance of identifying objective-oriented metrics when assessing the benefits of technology implementations. This may be a reason why broad 
performance measures do not consistently show the expected returns to IT implementations (Dehning et al. 2007) and more specifically, why firms face difficulty in measuring or quantifying the benefits of IT-related control initiatives (PwC 2006b, ITGI 2003).

Our results also support the PCAOB's recent encouragement regarding the external auditor's utilization of support provided by the auditee during the process of understanding and testing a client's system of internal controls. To the extent that an auditee's ICM technology initiatives provide evidence about the design and operating effectiveness of controls, external auditors are likely to find ICM technology an efficient and effective source of evidence. Our evidence is consistent with an auditee's use of ICM technology being a beneficial source of assistance in light of internal and external assurance outcomes.

With respect to the monitoring applications of technology, our results speak to the opportunities created by IT governance structures that implement technology-dependent processes to help assess and manage risk. PwC (2006a) notes that most organizations, to date, have failed to implement software tools in their IT governance efforts. However, as IT governance systems mature and firms establish their IT governance practices, the need to invest in software tools to support these ongoing efforts will emerge (PwC 2006a). Although IT governance concepts cover a wide range of objectives, PwC (2006a) asserts that currently most IT governance projects are focused on compliance and control objectives. In addition, the IT Governance Institute (ITGI 2008a) reports that IT for regulatory compliance is the top business issue affected by technology that executives and managers will face during the coming years. In turn, the need to monitor and measure the benefits added by such monitoring activities will also increase.

We encourage future research to examine the link between other types of ICM technology and specific outcomes. For example, to what extent does the maturity of a firm's internal control monitoring practices mitigate the benefits received from specific ICM technology? Although our study is conducted within the setting of SOX compliance efforts, 
the benefits of ICM technology could also be studied in other compliance or corporate initiative settings. For example, how do other specific ICM technologies aid in the compliance with other regulatory requirements over reporting and control, such as those governing healthcare and financial institutions?

Though our study documents benefit-oriented assurance outcomes, this research area remains fruitful with respect to the impact of ICM technology on other audit quality measures. For example, in an experimental setting, Bierstaker et al. (2009) document tradeoffs between the use of client-provided internal control documentation and the quality of external auditor decision making, whereby client-provided assistance can be a detriment to the auditor's ability to identify and document internal control problems. Likewise, it remains an empirical question as to whether ICM technology enhances audit quality (both internal and external) despite its association with audit efficiency and timeliness.

Similarly, it remains an open question as to how technology impacts other areas of internal control monitoring. COSO asserts the role of monitoring not only aids the financial reporting process, but also ultimately the organization's overall system of governance, including operational decision making. For example, Hunton et al. (2008) conduct an investigation into the impact of continuous monitoring on managerial decision-making. To the extent that control monitoring expands beyond a focus on financial reporting assurance, it remains an open question as to how ICM technology impacts managerial outcomes. 


\section{REFERENCES}

Adut, D., W. H. Cready, and T. J. Lopez. 2003. Restructuring charges and CEO cash compensation: A reexamination. The Accounting Review 78 (1): 169-192.

Ashbaugh-Skaife, H., D. W. Collins, and W. R. Kinney. 2007. The discovery and reporting of internal control deficiencies prior to SOX-mandated audit. Journal of Accounting and Economics 44 (1-2): 166-192.

Ashbaugh-Skaife, H., D. Collins, W. Kinney, and R. LaFond. 2008. The effect of SOX internal control deficiencies and their remediation on accrual quality. The Accounting Review 83 (1): 217-250. , and . The effect of SOX internal control deficiencies on firm risk and cost of equity. Journal of Accounting Research 47(1): 1-43.

Banker, R. D., H. Chang, and Y. Kao. 2002. Impact of information technology on public accounting firm productivity. Journal of Information Systems 16 (2): 209-222.

Barua, A., and T. Mukhopadhyay. 2000. Business value of information technologies: Past, present and future. In R.W. Zmud (Ed.), Framing the Domains of IT Management: Projecting the Future Through the Past: 65-84. Pinnaflex Educational Resources: Cincinnati, Ohio.

Bedard, J. C., M. L. Ettredge, and K. M. Johnstone. 2007. Using electronic audit workpaper systems in audit practice: Task analysis, learning, and resistance. Advances in Accounting Behavioral Research 10: 29-53.

Behn, B. K., D. L. Searcy, and J. B. Woodroof. 2006. A within firm analysis of current and expected future audit lag determinants. Journal of Information Systems 20 (1): 65-86.

Bierstaker, J. L., J. E. Hunton, and J.C. Thibodeau. 2009. Do client-prepared internal control documentation and business process flowcharts help or hinder an auditor's ability to identify missing controls. Auditing: A Journal of Practice and Theory 28 (1): 79-84.

Bible, L., L. Graham, and A. Rosman. 2005. Comparing auditors' performance in paper and electronic work environments. Journal of Accounting Auditing and Finance (March): $27-42$.

Brazel, J. F., C. P. Agoglia, and R. C. Hatfield. 2004. Electronic versus face-to-face review: The effects of alternative forms of review on auditors' performance. The Accounting Review 79 (4): 949-966.

, and L. Dang. 2008. The effect of ERP system implementations on the management of earnings and earnings release dates. Journal of Information Systems $22(2)$.

Chatterjee, D. C., V. J. Richardson, and R. Zmud. 2001. Examining the shareholder effects of new CIO position announcements. MIS Quarterly 25 (1): 43-70.

Coderre, D. 2006. Global Technology Audit Guide: Continuous Auditing Implications for Assurance, Monitoring, and Risk Assessment. Montvale, NJ: The Institute of Internal Auditors.

Committee of Sponsoring Organizations of the Treadway Commission (COSO). 1992. Internal Control - Integrated Framework. New York, NY: AICPA. . 2009a. Guidance on Monitoring Internal Control Systems- Volume 1:

Guidance. Durham, NC: Committee of Sponsoring Organizations of the Treadway Commission. . 2009b. Guidance on Monitoring Internal Control Systems - Volume II: Application. Durham, NC: Committee of Sponsoring Organizations of the Treadway Commission. 2009c. Guidance on Monitoring Internal Control Systems - Volume III: Examples. Durham, NC: Committee of Sponsoring Organizations of the Treadway Commission. 
Dehning, B., and V. J. Richardson. 2002. Returns on investments in information technology: A research synthesis. Journal of Information Systems 16 (1): 7-30. , and R. W. Zmud. 2003. The value relevance of announcements of transformational informational technology investments. MIS Quarterly 27 (4): 637. , and R. W. Zmud. 2007. The financial performance effects of ITbased supply chain management systems in manufacturing firms. Journal of Operations Management 25: 806-824.

Dewan, S., V. Gurbaxani, and C. Shi. 2007. Investigating the risk-return relationship of information technology investment: Firm-level empirical analysis. Management Science 53 (12): 1829-1842.

Dowling C. 2009. Appropriate audit support system use: The influence of auditor, audit team and firm factors. The Accounting Review 84 (3): 771-810. , and S. A. Leech. 2007. Audit support system design and decision aids: Current practice and opportunities for future research. International Journal of Accounting Information Systems 8: 92-116.

Doyle, J., W. Ge, and S. McVay. 2007. Determinants of weaknesses in internal control over financial reporting. Journal of Accounting \& Economics 44: 193-223.

Ernst \& Young. 2007. Sustain your GRC strategy with continuous controls monitoring.

Ettredge, M. L., C. Li, and L. Sun. 2006. The impact of SOX Section 404 internal control quality assessment on audit delay in the SOX era. Auditing: A Journal of Practice \& Theory 25 (2): 1-23.

Fischer, M. J. 1996. "Real-Izing" the benefits of new technologies as a source of audit evidence: An interpretive field study. Accounting, Organizations, and Society 23 $(2 / 3): 219-242$.

Ge, W., and S. McVay. 2005. The disclosure of material weaknesses in internal control after the Sarbanes-Oxley Act. Accounting Horizons 19 (3): 137-158.

Guay, W., and J. Hartford. 2000. The cash flow permanence and information content of dividend increases versus repurchases. Journal of Financial Economics 57: 385-415.

Gupta, P., and N. Nayar. 2007. Information content of control deficiency disclosures under the Sarbanes-Oxley Act: An empirical investigation. International Journal of Disclosure and Governance 4 (1): 3-18.

Hammersley, J. S., L. A. Myers, and C. Shakespeare, 2008. Market reactions to the disclosure of internal control weaknesses and to the characteristics of those weaknesses under section 302 of the Sarbanes Oxley Act of 2002. Review of Accounting Studies 13 (1): 141-165.

Hayes, D. C., J. E. Hunton, and J. L. Reck. 2001. Market reaction to ERP implementation announcements. Journal of Information Systems 15: 3-18.

Heckman, J., 1979. Sample selection bias as a specification error. Econometrica 47: 153-161.

Hitt, L. M., D. J. Wu, and X. Zhou. 2002. Investment in enterprise resource planning: Business impact and productivity measures. Journal of Management Information Systems 10: 71-98.

Hunton, J. E., B. Lippincott, and J. L. Reck. 2003. Enterprise resource planning systems: Comparing firm performance of adopters and nonadopters. International Journal of Accounting Information Systems 4: 165-184.

, E. G. Mauldin, and P. R. Wheeler. 2008. Potential Functional and Dysfunctional Effects of Continuous Monitoring. The Accounting Review 83 (6): 1551-1569.

Information Technology Governance Institute (ITGI). 2003. Board Briefing on IT Governance, $2^{\text {nd }}$ edition. Information Systems Assurance and Control Association (ISACA) Rolling Meadows, IL. 2005. Measuring and Demonstrating the Value of IT. Information Systems Assurance and Control Association (ISACA) Rolling Meadows, IL 
. 2006. ISACA/ITGI response to SEC concept release. Information Systems Assurance and Control Association (ISACA) Rolling Meadows, IL . 2008a.Top Business/Technology Issues Survey Results. Information Systems Assurance and Control Association (ISACA) Rolling Meadows, IL. .2008b.Enterprise Value: Governance of IT Investments: Getting Started with Value Management. Information Systems Assurance and Control Association (ISACA) Rolling Meadows, IL.

Janvrin. D., J. Bierstaker, and D. J. Lowe. 2008. An examination of audit information technology use and perceived importance. Accounting Horizons 22 (1): 1-21.

Knechel, W. R., and J. L. Payne. 2001. Additional evidence on audit report lag. Auditing: A Journal of Practice \& Theory 20 (1): 137-146.

Kobelsky, K., V. J. Richardson, R. E. Smith, and R. W. Zmud. 2008. Determinants and consequences of firm information technology budgets. The Accounting Review 83 (4): 957-995.

Kothari, S. P., Leone, A. J., Wasley, C. E., 2005. Performance matched discretionary accrual measures. Journal of Accounting Economics 39: 163-197.

KPMG. 2008. Continuous auditing and continuous monitoring: Transforming internal audit and management monitoring to create value.

Krishnan, J., D. Rama, and Y. Zhang. 2008. Costs to comply with SOX Section 404. Auditing: A Journal of Practice and Theory 27 (1): 169-186.

Lennox, C. S., and J. R. Francis. 2008. Selection models in accounting research. Working Paper (February 28, 2008). Available at SSRN: http://ssrn.com/abstract=1120796

Melville, N., K. Kraemer, and V. Gurbaxani. 2004. Review: Information technology and organizational performance: An integrative model of IT business value. MIS Quarterly 28 (2): $283-322$.

Messier, W. 1995. Research in and development of audit-decision aids. In Judgment and Decision-Making Research in Accounting and Auditing, edited by R. Ashton, and A. Ashton, 207-230. New York, NY: Cambridge University Press.

O'Donnell, E., and J. David. 2000. How information systems influence user decisions: A research framework and literature review. International Journal of Accounting Information Systems 1 (3): 178-203. , and J. J. Schultz. 2003. The influence of business-process-focused audit support software on analytical procedures judgments. Auditing: A Journal of Practice and Theory 22 (2): 265-279.

Pricewaterhouse Coopers (PWC). 2006a. IT Governance in Practice - Insight from Leading CIOs. New York, NY: Pricewaterhouse Coopers. , 2006b. Pricewaterhouse Coopers 2006 State of the Internal Audit Profession: Continuous Auditing Gains Momentum. New York, NY: Pricewaterhouse Coopers.

Public Company Accounting Oversight Board (PCAOB). 2007. Auditing Standard No. 5 An Audit of Internal Control Over Financial Reporting That Is Integrated with An Audit of Financial Statements. Washington, D.C.: PCAOB.

Raghunandan, K., and D. V. Rama. 2006. SOX section 404 material weakness disclosures and audit fees. Auditing: A Journal of Practice and Theory 25 (1): 99-104.

Standish Group. Chaos. Research Paper, 2004.

http://www.standishgroup.com/sample research/PDFpages/q3-spotlight.pdf

Tam, K. Y. 1998. The impact of information technology investments on firm performance and evaluation: Evidence from newly industrialized economics. Information Systems Research 9 (1): 85-98.

White, H., 1980. A heteroskedasticity-consistent covariance matrix estimator and a direct test for heteroskedasticity. Econometrica 48, 817-830. 
TABLE 1

Sample Description

Panel A - Distribution by Year

\begin{tabular}{rcccrr}
\hline & \multicolumn{4}{c}{ Control } \\
Year & SOX ICM Firms & \multicolumn{1}{c}{ Firms } & All \\
\hline & & Transform & Comply & & \\
2003 & 2 & 11 & 3,074 & 3,087 \\
2004 & 12 & 25 & 3686 & 3723 \\
2005 & 14 & 47 & 4044 & 4105 \\
2006 & 8 & 20 & 3850 & 3878 \\
\hline Total & 36 & 103 & 14,654 & 14,793
\end{tabular}

Panel B - Distribution by Two-Digit SIC

\begin{tabular}{|c|c|c|c|c|}
\hline \multirow[t]{2}{*}{ Two-Digit SIC Code } & \multicolumn{4}{|c|}{ Control } \\
\hline & Transform & Comply & & \\
\hline 13 - Oil \& Gas Extraction & 0 & 3 & 502 & 505 \\
\hline 14 - Mining \& Quarrying Of Nonmetallic Minerals & 1 & 0 & 21 & 22 \\
\hline 15 - Building Construction - General Contractors & 0 & 1 & 85 & 86 \\
\hline 20 - Food \& Kindred Products & 4 & 3 & 233 & 240 \\
\hline 21 - Tobacco Products & 0 & 2 & 19 & 21 \\
\hline 22 - Textile Mill Products & 0 & 1 & 33 & 34 \\
\hline 24 - Lumber \& Wood Products Except Furniture & 0 & 1 & 57 & 58 \\
\hline 26 - Paper \& Allied Products & 1 & 0 & 112 & 113 \\
\hline 27 - Printing Publishing \& Allied Industries & 1 & 2 & 138 & 141 \\
\hline 28 - Chemicals \& Allied Products & 1 & 3 & 1,294 & 1,298 \\
\hline 31 - Leather \& Leather Products & 1 & 0 & 39 & 40 \\
\hline 32 - Stone Clay Glass \& Concrete Products & 1 & 0 & 63 & 64 \\
\hline 33 - Primary Metal Industries & 0 & 3 & 168 & 171 \\
\hline 35 - Industrial \& Commercial Machinery \& Cmptr Equip. & 0 & 5 & 644 & 649 \\
\hline 36 - Electronic \& Other Electrical Equip. \& Components & 3 & 15 & 948 & 966 \\
\hline 37 - Transportation Equip. & 1 & 2 & 256 & 259 \\
\hline 38 - Measuring Analyzing Controlling Instruments & 1 & 7 & 716 & 724 \\
\hline 39 - Miscellaneous Manufacturing Industries & 0 & 1 & 76 & 77 \\
\hline 44 - Water Transportation & 2 & 1 & 101 & 104 \\
\hline 45 - Transportation By Air & 1 & 0 & 121 & 122 \\
\hline 48 - Communications & 3 & 2 & 520 & 525 \\
\hline 49 - Electric Gas \& Sanitary Services & 4 & 4 & 624 & 632 \\
\hline 50 - Wholesale Trade - Durable Goods & 1 & 3 & 223 & 227 \\
\hline 58 - Eating \& Drinking Places & 0 & 2 & 157 & 159 \\
\hline 59 - Miscellaneous Retail & 0 & 1 & 221 & 222 \\
\hline 60 - Depository Institutions & 3 & 3 & 1,406 & 1,412 \\
\hline 61 - Non-depository Credit Institutions & 1 & 2 & 165 & 168 \\
\hline 62 - Security \& Commodity Brokers Dealers & 1 & 0 & 204 & 205 \\
\hline 63 - Insurance Carriers & 2 & 6 & 532 & 540 \\
\hline 64 - Insurance Agents Brokers \& Service & 0 & 1 & 68 & 69 \\
\hline 67 - Holding \& Other Investment Offices & 1 & 4 & 780 & 785 \\
\hline 72 - Personal Services & 0 & 3 & 40 & 43 \\
\hline 73 - Business Services & 1 & 13 & 1,340 & 1,354 \\
\hline 80 - Health Services & 1 & 4 & 222 & 227 \\
\hline 83 - Social Services & 0 & 1 & 25 & 26 \\
\hline 87 - Engineering Acct Research Mgmt \& Related Services & 0 & 3 & 259 & 262 \\
\hline 99 - Non-classifiable Establishments & 0 & 1 & 44 & 45 \\
\hline All other industries & 0 & 0 & 2,198 & 2,198 \\
\hline Total & 36 & 103 & 14,654 & 14,793 \\
\hline
\end{tabular}


TABLE 2

\section{Variable Definitions}

Dependent Variables

Definition

Weaknesses The total number of material control weaknesses reported (“count_we” field in audit analytics).

Audit Fees Audit Fee Percent Change (calculated using the "matchfy_sum_audfees" field in audit analytics).

Audit Delays $\quad$ The number of days between the audit report date and the fiscal year end (using the "sig_date_of_op_s and fiscal_year_end_op" fields in audit analytics).

Test Variables

SOXICM

An indicator variable coded 1 if the firm implemented SOX-related ICM technology and 0 otherwise.

SOX ICM Transform

An indicator variable coded 1 if the firm implemented SOX-related ICM technology that is transformational in nature and 0 otherwise.

SOX ICM Comply

An indicator variable coded 1 if the firm implemented SOX-related ICM technology that is intended to comply only and 0 otherwise.

Control Variables

(alphabetic order)

Absolute Accruals

Assets

Auditor Change

Audit Fees

Bankruptcy Risk

Big 4

Extreme Sales Growth

The absolute value of performance-matched discretionary accruals estimated following Kothari et al. (2005).

The natural logarithm of total assets ("at" field in compustat).

An indicator variable coded 1 if there is a change in auditors and 0 otherwise (auditors are identified using the "auditor_fkey" field in audit analytics).

The natural logarithm of total audit fees (“matchfy_sum_audfees” field in audit analytics).

The decile rank of Altman's Z score.

An indicator variable if the firms auditor is a big 4 and 0 otherwise (big 4 auditors are identified using the "auditor_fkey" field in audit analytics).

An indicator variable coded 1 if the firm's industry-adjusted sales growth is in the top quintile of the sample and 0 otherwise (calculated using the "sale" field in compustat). 
TABLE 2

Variable Definitions (continued)

\section{Control Variables}

Firm Age

Foreign Transactions

Going Concern

Heckman

Leverage

Liquidity

Loss

Merger

Receivables and Inventory

Restatement

Restructuring

$R O A$

Segments

Trend

Weakness
The number of years the firm has been trading in a stock exchange constructed as the difference between the current year and the year when the firms started trading ("BEGDAT" field in crsp).

An indicator variable coded 1 if the firm reports foreign exchange income/loss ("fca" field in compustat) and 0 otherwise.

An indicator variable coded 1 if the firm's auditor issued a going concern opinion ("going_concern" field in audit analytics) and 0 otherwise.

The Inverse Mills ratio calculated using the estimation results from the following probit model: $\operatorname{Pr}(\mathrm{SOX} \operatorname{ICM}=1)=\mathrm{f}$ [size and financial health (lagged Assets, ROA, Altman's Z), IT Intensity (lagged industry-level IT expenditures scaled by total assets), Financial Reporting Quality (lagged Absolute Accruals), Assurance (lagged Audit Fees)].

The ratio of total debt to total assets.

The current ratio of total current assets ("act" field in compustat) to total current liabilities ("lct" field in compustat).

An indicator variable coded 1 if the firm reports a loss (calculated using net income - "ni" field in compustat) and 0 otherwise.

An indicator variable coded 1 if the firm engaged in mergers and acquisitions ("aqc" field in compustat) and 0 otherwise.

The ratio of the sum of net account receivables ("rect" field in compustat) and inventory ("invt" field in compustat) to total assets.

An indicator variable coded 1 if the firm reported a restatement ("res acco" field in audit analytics) and 0 otherwise.

Pre-tax restructuring charges ("rcp" field in compustat) scaled by market value of equity.

The ratio of net income ("ni" field in compustat) to total assets ("at" field in compustat).

The firm's number of geographical segments (calculated using the compustat segment file).

A linear trend measured as the difference between the current year and 2002.

An indicator variable coded 1 if a material weakness is reported and 0 otherwise (calculated using the "count_we" field in audit analytics). 
TABLE 3

Comparison of ICM technology (SOX ICM) Firms and Control Firms

\begin{tabular}{|c|c|c|c|c|c|c|c|}
\hline & \multicolumn{3}{|c|}{ SOX ICM Firms $(\mathrm{N}=139)$} & \multicolumn{3}{|c|}{ Control Firms $(N=14,654)$} & \multirow[b]{2}{*}{$\begin{array}{l}p \text { for mean } \\
\text { difference }\end{array}$} \\
\hline & Mean & Median & Std Dev & Mean & Median & Std Dev & \\
\hline Assets (in millions) & $15,271.060$ & $2,335.734$ & $40,033.420$ & $7,648.144$ & 969.271 & $26,890.530$ & $<0.001$ \\
\hline Firm Age & 29.345 & 17.000 & 26.879 & 18.636 & 12.000 & 19.222 & $<0.001$ \\
\hline Segments & 6.108 & 6.000 & 3.426 & 4.675 & 4.000 & 3.116 & $<0.001$ \\
\hline Foreign Transactions & 0.353 & 0.000 & 0.479 & 0.339 & 0.000 & 0.473 & 0.733 \\
\hline$R O A$ & 0.040 & 0.044 & 0.108 & 0.001 & 0.032 & 0.180 & 0.011 \\
\hline Loss & 0.101 & 0.000 & 0.302 & 0.219 & 0.000 & 0.414 & $<0.001$ \\
\hline Extreme Sales Growth & 0.050 & 0.000 & 0.219 & 0.168 & 0.000 & 0.374 & $<0.001$ \\
\hline Receivables and Inventory & 0.270 & 0.237 & 0.203 & 0.276 & 0.219 & 0.231 & 0.781 \\
\hline Liquidity & 2.095 & 1.612 & 1.768 & 2.478 & 1.535 & 2.524 & 0.074 \\
\hline Leverage & 0.193 & 0.133 & 0.195 & 0.181 & 0.118 & 0.203 & 0.495 \\
\hline Bankruptcy Risk & 6.165 & 6.000 & 2.264 & 5.999 & 6.000 & 2.458 & 0.425 \\
\hline Big 4 & 0.971 & 1.000 & 0.168 & 0.828 & 1.000 & 0.378 & $<0.001$ \\
\hline Auditor Change & 0.014 & 0.000 & 0.120 & 0.058 & 0.000 & 0.234 & 0.027 \\
\hline Merger & 0.568 & 1.000 & 0.497 & 0.380 & 0.000 & 0.485 & $<0.001$ \\
\hline Restructuring & $(0.003)$ & 0.000 & 0.012 & $(0.004)$ & 0.000 & 0.027 & 0.616 \\
\hline Restatement & 0.086 & 0.000 & 0.282 & 0.099 & 0.000 & 0.299 & 0.611 \\
\hline Going Concern & 0.007 & 0.000 & 0.085 & 0.019 & 0.000 & 0.138 & 0.298 \\
\hline Audit Fees (in thousands) & $4,723.053$ & $2,431.290$ & $6,152.908$ & $2,460.209$ & $1,120.980$ & $4,126.909$ & $<0.001$ \\
\hline Absolute Accruals & 0.048 & 0.028 & 0.061 & 0.061 & 0.029 & 0.126 & 0.234 \\
\hline IT Spending * & 0.035 & 0.029 & 0.019 & 0.035 & 0.028 & 0.021 & 0.439 \\
\hline
\end{tabular}

In this table we define Assets in millions for exposition purposes. The natural log of Assets is used in all multivariate models. All variables are measured at year ${ }_{t+1}$ (the year of interest). All continuous variables are winsorized at the $1 / 99 \%$ to mitigate the influence of outliers. The sample period is 2003 to 2006.

* Since our IT spending dataset ends in 2005, for descriptive purposes, we measure IT spending at year t to maximize the number of firm-year observations with available IT spending data. The number of observations for treatment (control) firms is 99 (9,729).

See Table 2 for detailed variable definitions. 
TABLE 4

Intertemporal Analysis of Dependent Variables

Panel A - Number of Material Weaknesses

\begin{tabular}{|c|c|c|c|c|c|c|c|c|c|}
\hline \multirow[b]{2}{*}{ All Years } & \multicolumn{4}{|c|}{ SOX ICM Firms } & \multicolumn{4}{|c|}{ Control Firms } & \multirow{2}{*}{$\begin{array}{l}p \text { for mean } \\
\text { difference }\end{array}$} \\
\hline & $\mathbf{N}$ & Mean & Median & Std Dev & $\mathbf{N}$ & Mean & Median & Std Dev & \\
\hline Year $_{\mathrm{t}-1}$ & 57 & 0.649 & 0.000 & 1.894 & 5412 & 0.322 & 0.000 & 1.240 & 0.049 \\
\hline Year $_{t}$ & 104 & 0.163 & 0.000 & 0.593 & 9545 & 0.278 & 0.000 & 1.115 & 0.148 \\
\hline Year $_{t+1}$ & $134^{+}$ & 0.097 & 0.000 & 0.440 & 14654 & 0.259 & 0.000 & 1.086 & 0.043 \\
\hline
\end{tabular}

Panel B - Audit Fee Percent Change

\begin{tabular}{|c|c|c|c|c|c|c|c|c|c|}
\hline \multirow[b]{2}{*}{ All Years } & \multicolumn{4}{|c|}{ SOX ICM Firms } & \multicolumn{4}{|c|}{ Control Firms } & \multirow[b]{2}{*}{$\begin{array}{l}p \text { for mear } \\
\text { difference }\end{array}$} \\
\hline & $\mathbf{N}$ & Mean & Median & Std Dev & $\mathbf{N}$ & Mean & Median & Std Dev & \\
\hline Year $_{t-1}$ & 122 & 0.762 & 0.351 & 1.114 & 11077 & 0.644 & 0.274 & 1.082 & 0.229 \\
\hline Year $_{t}$ & 138 & 0.481 & 0.160 & 0.824 & 14265 & 0.569 & 0.205 & 1.027 & 0.158 \\
\hline Year $_{t+1}$ & 139 & 0.243 & 0.026 & 0.574 & 14654 & 0.478 & 0.140 & 0.873 & $<0.001$ \\
\hline
\end{tabular}

Panel C - Audit Delay Percent Change

\begin{tabular}{|c|c|c|c|c|c|c|c|c|c|}
\hline \multirow[b]{2}{*}{ All Years } & \multicolumn{4}{|c|}{ SOX ICM Firms } & \multicolumn{4}{|c|}{ Control Firms } & \multirow[b]{2}{*}{$\begin{array}{l}p \text { for mean } \\
\text { difference }\end{array}$} \\
\hline & $\mathbf{N}$ & Mean & Median & Std Dev & $\mathbf{N}$ & Mean & Median & Std Dev & \\
\hline Year $_{t-1}$ & 125 & 0.351 & 0.065 & 0.860 & 11325 & 0.272 & 0.029 & 0.812 & 0.283 \\
\hline Year $_{t}$ & 139 & 0.170 & 0.000 & 0.517 & 14474 & 0.230 & 0.000 & 0.750 & 0.174 \\
\hline Year $_{\mathrm{t}+1}$ & 139 & 0.055 & 0.000 & 0.323 & 14654 & 0.181 & 0.000 & 0.666 & 0.013 \\
\hline
\end{tabular}

$p$ are based on two-tail tests.

+ The number of SOX ICM firms (134) reported in this panel differs from our total number of treatment firms (139) because five treatment firms did not present a Section 404 Control Weakness Report in any of the sample years.

See Table 2 for detailed variable definitions. 
Table 5

The Impact of SOX-related ICM technology (SOX ICM) on The Number of Weaknesses

\begin{tabular}{|c|c|c|c|c|c|c|c|}
\hline & \multirow{2}{*}{$\begin{array}{l}\text { Predicted } \\
\text { Sign }\end{array}$} & \multicolumn{6}{|c|}{ DV = Number of Weaknesses at year ${ }_{t+1}$} \\
\hline & & (1) & $(2)$ & (3) & (4) & (5) & (6) \\
\hline \multirow[t]{2}{*}{ SOXICM } & - & $-0.103^{* * *}$ & $-0.161 * * *$ & $-0.100 * * *$ & & & \\
\hline & & $(0.006)$ & $(<0.001)$ & $(0.017)$ & & & \\
\hline \multirow[t]{2}{*}{ SOX ICM Transform } & - & & & & $-0.151^{* * *}$ & $-0.122 * *$ & $-0.093 *$ \\
\hline & & & & & $(0.002)$ & $(0.023)$ & $(0.081)$ \\
\hline \multirow[t]{2}{*}{ SOX ICM Comply } & - & & & & $-0.086 * *$ & $-0.175^{* * *}$ & $-0.103 * *$ \\
\hline & & & & & $(0.047)$ & $(0.001)$ & $(0.041)$ \\
\hline \multirow{2}{*}{ Assets } & - & $-0.037 * * *$ & $-0.125 * * *$ & $-0.053 * * *$ & $-0.037 * * *$ & $-0.125^{* * *}$ & $-0.053 * * *$ \\
\hline & & $(<0.001)$ & $(<0.001)$ & $(<0.001)$ & $(<0.001)$ & $(<0.001)$ & $(<0.001)$ \\
\hline \multirow{2}{*}{ Firm Age } & - & 0.003 & -0.010 & -0.002 & 0.003 & -0.010 & -0.002 \\
\hline & & $(0.398)$ & $(0.181)$ & $(0.422)$ & $(0.397)$ & $(0.180)$ & $(0.421)$ \\
\hline \multirow[t]{2}{*}{ Loss } & + & $0.377 * * *$ & $0.174 * * *$ & $0.262 * * *$ & $0.377 * * *$ & $0.174 * * *$ & $0.262 * * *$ \\
\hline & & $(<0.001)$ & $(<0.001)$ & $(<0.001)$ & $(<0.001)$ & $(<0.001)$ & $(<0.001)$ \\
\hline \multirow[t]{2}{*}{ Bankruptcy Risk } & - & $-0.029 * * *$ & $-0.039 * * *$ & $-0.029 * * *$ & $-0.029 * * *$ & $-0.039 * * *$ & $-0.029 * * *$ \\
\hline & & $(<0.001)$ & $(<0.001)$ & $(<0.001)$ & $(<0.001)$ & $(<0.001)$ & $(<0.001)$ \\
\hline \multirow[t]{2}{*}{ Segments } & + & $0.026^{* * *}$ & -0.001 & 0.017 & $0.026 * * *$ & -0.001 & $0.017 * * *$ \\
\hline & & $(<0.001)$ & $(0.419)$ & $(<0.001)$ & $(<0.001)$ & $(0.418)$ & $(<0.001)$ \\
\hline \multirow[t]{2}{*}{ Foreign Transactions } & + & $0.031^{*}$ & $0.098 * * *$ & $0.088 * * *$ & $0.031^{*}$ & $0.098 * * *$ & $0.088 * * *$ \\
\hline & & $(0.053)$ & $(<0.001)$ & $(<0.001)$ & $(0.053)$ & $(<0.001)$ & $(<0.001)$ \\
\hline \multirow[t]{2}{*}{ Merger } & + & $0.039 * *$ & $-0.031 * *$ & 0.023 & $0.039 * *$ & $-0.031 * *$ & 0.023 \\
\hline & & $(0.022)$ & $(0.050)$ & $(0.132)$ & $(0.022)$ & $(0.050)$ & $(0.132)$ \\
\hline \multirow[t]{2}{*}{ Extreme Sales Growth } & + & -0.003 & -0.007 & 0.013 & -0.003 & -0.007 & 0.013 \\
\hline & & $(0.456)$ & $(0.380)$ & $(0.316)$ & $(0.455)$ & $(0.380)$ & $(0.316)$ \\
\hline \multirow[t]{2}{*}{ Restructuring } & - & $-0.000 * * *$ & $-0.000 * *$ & $-0.000 * *$ & $-0.000 * * *$ & $-0.000 * *$ & $-0.000 * * *$ \\
\hline & & $(<0.001)$ & $(0.018)$ & $(<0.001)$ & $(<0.001)$ & $(0.018)$ & $(<0.001)$ \\
\hline \multirow[t]{2}{*}{ Restatement } & + & & $0.725^{* * *}$ & $0.831^{* * *}$ & & $0.725^{* * *}$ & $0.831 * * *$ \\
\hline & & & $(<0.001)$ & $(<0.001)$ & & $(<0.001)$ & $(<0.001)$ \\
\hline \multirow[t]{2}{*}{ Going Concern } & + & & $0.343 * * *$ & $0.490 * * *$ & & $0.343 * * *$ & $0.490 * * *$ \\
\hline & & & $(0.002)$ & $(<0.001)$ & & $(0.002)$ & $(<0.001)$ \\
\hline \multirow[t]{2}{*}{ Audit Fees } & + & & $0.223 * * *$ & & & $0.223 * * *$ & \\
\hline & & & $(<0.001)$ & & & $(<0.001)$ & \\
\hline \multirow[t]{2}{*}{ Absolute Accruals } & + & & $0.289^{* * *}$ & & & $0.289^{* * *}$ & \\
\hline & & & $(0.007)$ & & & $(0.007)$ & \\
\hline \multirow[t]{2}{*}{ Heckman } & $?$ & & & $-0.241 * *$ & & & $-0.241^{*}$ \\
\hline & & & & $(0.004)$ & & & $(-0.053)$ \\
\hline \multirow[t]{2}{*}{ Trend } & $?$ & $-0.098 * * *$ & $-0.086^{* * *}$ & $-0.105 * * *$ & $-0.098 * * *$ & $-0.086^{* * *}$ & $0.000 * * *$ \\
\hline & & $(<0.001)$ & $(<0.001)$ & $(<0.001)$ & $(<0.001)$ & $(<0.001)$ & $(0.004)$ \\
\hline \multirow[t]{2}{*}{ Intercept } & & $0.704 * * *$ & $-1.653^{* * *}$ & $1.472 * * *$ & $0.704 * * *$ & $-1.653 * * *$ & $1.472 * * *$ \\
\hline & & $(<0.001)$ & $(<0.001)$ & $(<0.001)$ & $(<0.001)$ & $(<0.001)$ & $(<0.001)$ \\
\hline \multicolumn{2}{|l|}{ Observations $^{+}$} & 14,788 & 14,788 & 12,156 & 14,788 & 14,788 & 12,156 \\
\hline \multicolumn{2}{|l|}{ R2 } & 0.045 & 0.120 & 0.105 & 0.045 & 0.120 & 0.105 \\
\hline $\mathrm{F}$ & & 41.874 & 38.943 & 39.309 & 38.630 & 36.571 & 36.750 \\
\hline$p$ for Model & & $(<0.001)$ & $(<0.001)$ & $(<0.001)$ & $(<0.001)$ & $(<0.001)$ & $(<0.001)$ \\
\hline $\begin{array}{l}* * * p<0.01, * * p<0.05 \\
\text { are measured at year }\end{array}$ & two-tai & $\begin{array}{l}\text { t unless a d } \\
\text { bles are wi }\end{array}$ & $\begin{array}{l}\text { ctional prec } \\
\text { orized at the }\end{array}$ & $99 \%$ to mit & $\begin{array}{l}p \text { reported ir } \\
\text { gate the influ }\end{array}$ & arentheses. A & $\begin{array}{l}\text { ll variables } \\
\text { The }\end{array}$ \\
\hline
\end{tabular}


Table 6

The Impact of SOX-related ICM technology (SOX ICM) on Subsequent Audit Fees

\begin{tabular}{|c|c|c|c|c|c|c|c|}
\hline & \multirow{2}{*}{$\begin{array}{c}\text { Predicted } \\
\text { Sign }\end{array}$} & \multicolumn{6}{|c|}{ DV $=$ Audit Fee Percent Change (from year $t$ to $t+1$ ) } \\
\hline & & (1) & $(2)$ & (3) & (4) & (5) & (6) \\
\hline SOX ICM & - & $\begin{array}{l}-0.151 * * * \\
(0.001)\end{array}$ & $\begin{array}{l}-0.141 * * * \\
(0.002)\end{array}$ & $\begin{array}{l}-0.071^{*} \\
(0.082)\end{array}$ & & & \\
\hline SOX ICM Transform & - & & & & $\begin{array}{l}-0.269 * * * \\
(0.001)\end{array}$ & $\begin{array}{l}-0.261 * * * \\
(0.001)\end{array}$ & $\begin{array}{l}-0.188 * * \\
(0.011)\end{array}$ \\
\hline SOX ICM Comply & - & & & & $\begin{array}{l}-0.109 * * \\
(0.026)\end{array}$ & $\begin{array}{l}-0.099 * * \\
(0.040)\end{array}$ & $\begin{array}{l}-0.031 \\
(0.311)\end{array}$ \\
\hline$\Delta$ Assets & + & $\begin{array}{l}2.946^{* * *} \\
(<0.001)\end{array}$ & $\begin{array}{c}2.963 * * * \\
(<0.001)\end{array}$ & $\begin{array}{l}2.415^{* * *} \\
(<0.001)\end{array}$ & $\begin{array}{l}2.945^{* * *} \\
(<0.001)\end{array}$ & $\begin{array}{l}2.963^{* * *} \\
(<0.001)\end{array}$ & $\begin{array}{l}2.415^{* * * *} \\
(<0.001)\end{array}$ \\
\hline$\Delta$ Receivables and Inventory & + & $\begin{array}{l}0.047 * * \\
(0.013)\end{array}$ & $\begin{array}{l}0.047 * * \\
(0.014)\end{array}$ & $\begin{array}{c}0.023 \\
(0.156)\end{array}$ & $\begin{array}{c}0.047 * * \\
(0.013)\end{array}$ & $\begin{array}{l}0.047^{* *} \\
(0.014)\end{array}$ & $\begin{array}{c}0.023 \\
(0.158)\end{array}$ \\
\hline$\Delta$ Foreign Transactions & + & $\begin{array}{c}0.021 \\
(0.256)\end{array}$ & $\begin{array}{c}0.021 \\
(0.261)\end{array}$ & $\begin{array}{c}0.022 \\
(0.255)\end{array}$ & $\begin{array}{c}0.021 \\
(0.255)\end{array}$ & $\begin{array}{c}0.021 \\
(0.260)\end{array}$ & $\begin{array}{c}0.022 \\
(0.256)\end{array}$ \\
\hline$\Delta$ Segments & + & $\begin{array}{l}0.094 * * * \\
(0.006)\end{array}$ & $\begin{array}{l}0.092 * * * \\
(0.007)\end{array}$ & $\begin{array}{l}0.069 * * \\
(0.038)\end{array}$ & $\begin{array}{l}0.094 * * * \\
(0.006)\end{array}$ & $\begin{array}{l}0.092 * * * \\
(0.007)\end{array}$ & $\begin{array}{l}0.069 * * \\
(0.039)\end{array}$ \\
\hline$\Delta$ Liquidity & - & $\begin{array}{l}-0.067 * * * \\
(<0.001)\end{array}$ & $\begin{array}{l}-0.039 * * \\
(0.027)\end{array}$ & $\begin{array}{l}-0.072 * * * \\
(<0.001)\end{array}$ & $\begin{array}{l}-0.067 * * * \\
(<0.001)\end{array}$ & $\begin{array}{l}-0.039 * * \\
(0.027)\end{array}$ & $\begin{array}{l}-0.072 * * * \\
(<0.001)\end{array}$ \\
\hline$\Delta$ Leverage & + & $\begin{array}{l}0.007 * * * \\
(0.002)\end{array}$ & $\begin{array}{l}0.005^{* *} \\
(0.011)\end{array}$ & $\begin{array}{c}0.004 * \\
(0.065)\end{array}$ & $\begin{array}{l}0.007 * * * \\
(0.002)\end{array}$ & $\begin{array}{l}0.005^{* *} \\
(0.011)\end{array}$ & $\begin{array}{c}0.004 * \\
(0.064)\end{array}$ \\
\hline$\triangle R O A$ & - & $\begin{array}{c}0.001 \\
(0.370)\end{array}$ & $\begin{array}{c}0.001 \\
(0.320)\end{array}$ & $\begin{array}{l}-0.000 \\
(0.423)\end{array}$ & $\begin{array}{c}0.001 \\
(0.371)\end{array}$ & $\begin{array}{c}0.001 \\
(0.321)\end{array}$ & $\begin{array}{l}-0.000 \\
(0.422)\end{array}$ \\
\hline$\Delta$ Going Concern & + & $\begin{array}{c}0.000 \\
(0.498)\end{array}$ & $\begin{array}{c}0.001 \\
(0.496)\end{array}$ & $\begin{array}{l}-0.007 \\
(0.457)\end{array}$ & $\begin{array}{l}0.000 \\
(0.499)\end{array}$ & $\begin{array}{l}0.000 \\
(0.497)\end{array}$ & $\begin{array}{l}-0.007 \\
(0.455)\end{array}$ \\
\hline$\Delta B i g 4$ & + & $\begin{array}{l}0.336^{* * *} \\
(<0.001)\end{array}$ & $\begin{array}{l}0.336^{* * *} \\
(<0.001)\end{array}$ & $\begin{array}{l}0.328^{* * *} \\
(<0.001)\end{array}$ & $\begin{array}{l}0.336^{* * *} \\
(<0.001)\end{array}$ & $\begin{array}{l}0.336^{* * *} \\
(<0.001)\end{array}$ & $\begin{array}{l}0.328^{* * *} \\
(<0.001)\end{array}$ \\
\hline$\Delta$ Weaknesses & + & $\begin{array}{c}0.441 * * * \\
(<0.001)\end{array}$ & $\begin{array}{l}0.436^{* * *} \\
(<0.001)\end{array}$ & $\begin{array}{l}0.410^{* * * *} \\
(<0.001)\end{array}$ & $\begin{array}{l}0.441 * * * \\
(<0.001)\end{array}$ & $\begin{array}{l}0.436^{* * *} \\
(<0.001)\end{array}$ & $\begin{array}{l}0.410^{* * *} \\
(<0.001)\end{array}$ \\
\hline$\Delta$ Firm Age & $?$ & & $\begin{array}{l}-0.014 \\
(0.321)\end{array}$ & $\begin{array}{l}-0.079 * * * \\
(0.008)\end{array}$ & & $\begin{array}{l}-0.014 \\
(0.322)\end{array}$ & $\begin{array}{l}-0.078^{* * *} \\
(0.008)\end{array}$ \\
\hline$\Delta$ Restatement & + & & $\begin{array}{l}0.090^{* * *} \\
(<0.001)\end{array}$ & $\begin{array}{l}0.087 * * * \\
(<0.001)\end{array}$ & & $\begin{array}{l}0.090 * * * \\
(<0.001)\end{array}$ & $\begin{array}{l}0.087 * * * \\
(<0.001)\end{array}$ \\
\hline$\Delta$ Restructuring & - & & $\begin{array}{l}-0.000 \\
(0.388)\end{array}$ & $\begin{array}{c}0.001 \\
(0.216)\end{array}$ & & $\begin{array}{l}-0.000 \\
(0.392)\end{array}$ & $\begin{array}{c}0.001 \\
(0.214)\end{array}$ \\
\hline$\Delta$ Bankruptcy Risk & - & & $\begin{array}{l}-0.156^{* * *} \\
(<0.001)\end{array}$ & $\begin{array}{l}-0.084 * * * \\
(0.007)\end{array}$ & & $\begin{array}{l}-0.156^{* * *} \\
(<0.001)\end{array}$ & $\begin{array}{l}-0.084 * * * \\
(0.007)\end{array}$ \\
\hline$\Delta$ Absolute Accruals & + & & $\begin{array}{c}0.001 \\
(0.251)\end{array}$ & & & $\begin{array}{c}0.001 \\
(0.253)\end{array}$ & \\
\hline Heckman & $?$ & & & $\begin{array}{l}0.578 * * * \\
(<0.001)\end{array}$ & & & $\begin{array}{l}0.577 * * * \\
(<0.001)\end{array}$ \\
\hline Trend & $?$ & $\begin{array}{l}-0.329 * * * \\
(<0.001)\end{array}$ & $\begin{array}{l}-0.328 * * * \\
(<0.001)\end{array}$ & $\begin{array}{l}-0.323^{* * *} \\
(<0.001)\end{array}$ & $\begin{array}{l}-0.329 * * * \\
(<0.001)\end{array}$ & $\begin{array}{l}-0.328^{* * *} \\
(<0.001)\end{array}$ & $\begin{array}{l}-0.323 * * * \\
(<0.001)\end{array}$ \\
\hline Intercept & & $\begin{array}{l}1.256^{* * * *} \\
(<0.001)\end{array}$ & $\begin{array}{l}1.254^{* * * *} \\
(<0.001)\end{array}$ & $\begin{array}{l}-0.307 * * * \\
(<0.001)\end{array}$ & $\begin{array}{l}1.256^{* * * *} \\
(<0.001)\end{array}$ & $\begin{array}{l}1.254^{* * *} \\
(<0.001)\end{array}$ & $\begin{array}{l}-0.305^{* * *} \\
(<0.001)\end{array}$ \\
\hline Observations & & 14,793 & 14,793 & 12,161 & 14,793 & 14,793 & 12,161 \\
\hline R2 & & 0.263 & 0.266 & 0.307 & 0.263 & 0.266 & 0.307 \\
\hline $\begin{array}{l}\mathrm{F} \\
p \text { for Model }\end{array}$ & & $\begin{array}{l}311.864 \\
(<0.001)\end{array}$ & $\begin{array}{l}222.619 \\
(<0.001)\end{array}$ & $\begin{array}{l}212.969 \\
(<0.001)\end{array}$ & $\begin{array}{l}288.153 \\
(<0.001)\end{array}$ & $\begin{array}{l}210.438 \\
(<0.001)\end{array}$ & $\begin{array}{l}201.300 \\
(<0.001)\end{array}$ \\
\hline
\end{tabular}

See Table 2 for a detailed definition of variables. 
Table 7

The Impact of SOX-related ICM technology (SOX ICM) on Subsequent Audit Delays

\begin{tabular}{|c|c|c|c|c|c|c|c|}
\hline & \multirow{2}{*}{$\begin{array}{l}\text { Predicted } \\
\text { Sign }\end{array}$} & \multicolumn{6}{|c|}{ DV = Audit Delays Percent Change (from year $t$ to $t+1$ ) } \\
\hline & & (1) & $(2)$ & (3) & (4) & (5) & (6) \\
\hline SOX ICM & - & $\begin{array}{l}-0.060 * * \\
(0.015)\end{array}$ & $\begin{array}{l}-0.058^{* *} \\
(0.017)\end{array}$ & $\begin{array}{l}-0.063^{* *} \\
(0.030)\end{array}$ & & & \\
\hline SOX ICM Transform & - & & & & $\begin{array}{l}-0.134 * * * \\
(0.001)\end{array}$ & $\begin{array}{l}-0.133 * * * \\
(0.001)\end{array}$ & $\begin{array}{l}-0.149 * * * \\
(0.003)\end{array}$ \\
\hline SOX ICM Comply & - & & & & $\begin{array}{l}-0.034 \\
(0.152)\end{array}$ & $\begin{array}{l}-0.032 \\
(0.168)\end{array}$ & $\begin{array}{l}-0.032 \\
(0.206)\end{array}$ \\
\hline$\Delta$ Assets & - & $\begin{array}{l}-0.431 * * * \\
(<0.001)\end{array}$ & $\begin{array}{l}-0.427 * * * \\
(<0.001)\end{array}$ & $\begin{array}{l}-0.084 \\
(0.244)\end{array}$ & $\begin{array}{l}-0.431 * * * \\
(<0.001)\end{array}$ & $\begin{array}{l}-0.427 * * * \\
(<0.001)\end{array}$ & $\begin{array}{l}-0.084 \\
(0.244)\end{array}$ \\
\hline$\triangle R O A$ & - & $\begin{array}{l}-0.002 \\
(0.145)\end{array}$ & $\begin{array}{l}-0.002 \\
(0.140)\end{array}$ & $\begin{array}{l}-0.003 \\
(0.121)\end{array}$ & $\begin{array}{l}-0.002 \\
(0.144)\end{array}$ & $\begin{array}{l}-0.002 \\
(0.139)\end{array}$ & $\begin{array}{l}-0.003 \\
(0.120)\end{array}$ \\
\hline$\Delta$ Leverage & + & $\begin{array}{l}-0.001 \\
(0.219)\end{array}$ & $\begin{array}{l}-0.002 \\
(0.107)\end{array}$ & $\begin{array}{l}-0.000 \\
(0.400)\end{array}$ & $\begin{array}{l}-0.001 \\
(0.220)\end{array}$ & $\begin{array}{l}-0.002 \\
(0.108)\end{array}$ & $\begin{array}{l}-0.000 \\
(0.403)\end{array}$ \\
\hline$\Delta$ Going Concern & + & $\begin{array}{c}0.035 \\
(0.217)\end{array}$ & $\begin{array}{c}0.032 \\
(0.233)\end{array}$ & $\begin{array}{c}0.072 * \\
(0.072)\end{array}$ & $\begin{array}{c}0.034 \\
(0.218)\end{array}$ & $\begin{array}{c}0.032 \\
(0.234)\end{array}$ & $\begin{array}{c}0.071^{*} \\
(0.073)\end{array}$ \\
\hline$\Delta$ Restructuring & - & $\begin{array}{c}0.000 \\
(0.417)\end{array}$ & $\begin{array}{c}0.000 \\
(0.451)\end{array}$ & $\begin{array}{c}0.000 \\
(0.406)\end{array}$ & $\begin{array}{c}0.000 \\
(0.415)\end{array}$ & $\begin{array}{c}0.000 \\
(0.449)\end{array}$ & $\begin{array}{c}0.000 \\
(0.404)\end{array}$ \\
\hline$\Delta$ Segments & + & $\begin{array}{l}-0.028 \\
(0.133)\end{array}$ & $\begin{array}{l}-0.030 \\
(0.118)\end{array}$ & $\begin{array}{c}0.016 \\
(0.304)\end{array}$ & $\begin{array}{l}-0.029 \\
(0.131)\end{array}$ & $\begin{array}{l}-0.030 \\
(0.117)\end{array}$ & $\begin{array}{c}0.015 \\
(0.308)\end{array}$ \\
\hline$\Delta$ Loss & + & $\begin{array}{c}0.020 \\
(0.081)\end{array}$ & $\begin{array}{c}0.002 \\
(0.442)\end{array}$ & $\begin{array}{c}0.010 \\
(0.280)\end{array}$ & $\begin{array}{c}0.020^{*} \\
(0.082)\end{array}$ & $\begin{array}{c}0.002 \\
(0.445)\end{array}$ & $\begin{array}{c}0.010 \\
(0.282)\end{array}$ \\
\hline$\Delta$ Restatement & + & $\begin{array}{l}0.027 * * \\
(0.036)\end{array}$ & $\begin{array}{l}0.027 * * \\
(0.038)\end{array}$ & $\begin{array}{l}0.037^{* *} \\
(0.015)\end{array}$ & $\begin{array}{l}0.027 * * \\
(0.036)\end{array}$ & $\begin{array}{l}0.027 * * \\
(0.038)\end{array}$ & $\begin{array}{l}0.037 * * \\
(0.015)\end{array}$ \\
\hline$\Delta$ Audit Fees & + & $\begin{array}{l}0.148^{* * *} \\
(<0.001)\end{array}$ & $\begin{array}{l}0.147 * * * \\
(<0.001)\end{array}$ & & $\begin{array}{c}0.148^{* * * *} \\
(<0.001)\end{array}$ & $\begin{array}{l}0.147 * * * \\
(<0.001)\end{array}$ & \\
\hline$\Delta$ Weaknesses & + & $\begin{array}{l}0.356^{* * * *} \\
(<0.001)\end{array}$ & $\begin{array}{l}0.354 * * * \\
(<0.001)\end{array}$ & $\begin{array}{l}0.434 * * * \\
(<0.001)\end{array}$ & $\begin{array}{c}0.356^{* * * *} \\
(<0.001)\end{array}$ & $\begin{array}{l}0.354 * * * \\
(<0.001)\end{array}$ & $\begin{array}{l}0.435^{* * *} \\
(<0.001)\end{array}$ \\
\hline$\Delta$ Auditor Change & + & $\begin{array}{l}-0.009 \\
(0.361)\end{array}$ & $\begin{array}{l}-0.010 \\
(0.347)\end{array}$ & $\begin{array}{l}-0.013 \\
(0.333)\end{array}$ & $\begin{array}{l}-0.009 \\
(0.360)\end{array}$ & $\begin{array}{l}-0.010 \\
(0.346)\end{array}$ & $\begin{array}{l}-0.013 \\
(0.332)\end{array}$ \\
\hline$\Delta$ Firm Age & + & & $\begin{array}{l}0.058 * * * \\
(0.008)\end{array}$ & $\begin{array}{l}0.052 * * \\
(0.036)\end{array}$ & & $\begin{array}{l}0.058^{* * *} \\
(0.008)\end{array}$ & $\begin{array}{l}0.052^{* *} \\
(0.035)\end{array}$ \\
\hline$\Delta$ Bankruptcy Risk & - & & $\begin{array}{l}-0.098 * * * \\
(<0.001)\end{array}$ & $\begin{array}{l}-0.116^{* * *} \\
(<0.001)\end{array}$ & & $\begin{array}{l}-0.098 * * * \\
(<0.001)\end{array}$ & $\begin{array}{l}-0.116^{* * *} \\
(<0.001)\end{array}$ \\
\hline$\Delta$ Absolute Accruals & + & & $\begin{array}{l}0.002 * * \\
(0.020)\end{array}$ & & & $\begin{array}{l}0.002 * * \\
(0.020)\end{array}$ & \\
\hline Heckman & $?$ & & & $\begin{array}{c}0.107 * * \\
(<0.001)\end{array}$ & & & $\begin{array}{r}0.106^{*} \\
(<0.001)\end{array}$ \\
\hline Trend & $?$ & $\begin{array}{l}-0.126^{* * *} \\
(<0.001)\end{array}$ & $\begin{array}{l}-0.127 * * * \\
(<0.001)\end{array}$ & $\begin{array}{l}-0.166^{* * *} \\
(<0.001)\end{array}$ & $\begin{array}{l}-0.126^{* * *} \\
(<0.001)\end{array}$ & $\begin{array}{l}-0.127 * * * \\
(<0.001)\end{array}$ & $\begin{array}{l}-0.166^{* * * *} \\
(<0.001)\end{array}$ \\
\hline Intercept & & $\begin{array}{l}0.435^{* * *} \\
(<0.001)\end{array}$ & $\begin{array}{l}0.427 * * * \\
(<0.001)\end{array}$ & $\begin{array}{l}0.304^{* * *} \\
(<0.001)\end{array}$ & $\begin{array}{c}0.435^{* * *} \\
(<0.001)\end{array}$ & $\begin{array}{l}0.427 * * * \\
(<0.001)\end{array}$ & $\begin{array}{l}0.305^{* * *} \\
(<0.001)\end{array}$ \\
\hline Observations & & 14,793 & 14,793 & 12,161 & 14,793 & 14,793 & 12,161 \\
\hline R2 & & 0.183 & 0.185 & 0.164 & 0.183 & 0.185 & 0.164 \\
\hline $\begin{array}{l}\mathrm{F} \\
p \text { for Model }\end{array}$ & & $\begin{array}{l}120.780 \\
(<0.001)\end{array}$ & $\begin{array}{c}98.949 \\
(<0.001)\end{array}$ & $\begin{array}{c}80.430 \\
(<0.001)\end{array}$ & $\begin{array}{l}112.506 \\
(<0.001)\end{array}$ & $\begin{array}{c}93.407 \\
(<0.001)\end{array}$ & $\begin{array}{c}75.592 \\
(<0.001)\end{array}$ \\
\hline
\end{tabular}

See Table 2 for a detailed definition of variables. 


\title{
Appendix
}

\section{Example of Press Release for Firm Making SOX-related ICM technology Announcement for Transformative Role}

\author{
PepsiAmericas Chooses Nth Orbit for Sarbanes-Oxley Compliance; Global Pepsi Bottler Selects Certus \\ Software for Managing Compliance Initiative
}

DATELINE: SAN JOSE, Calif., May 3, 2004

"PepsiAmericas has always taken a long-term view of our financial and business practices," said Michael Durkin, Executive Vice President and Chief Financial Officer, PepsiAmericas. "We choose partners who can support both our short and long-term objectives. When searching for a Sarbanes-Oxley solution, we wanted a firm that could address our immediate certification requirements but also would help us leverage our long-term sustainment efforts. After careful evaluation, we chose Certus based on its ability to provide a comprehensive solution. We believe that Certus has the capability to go beyond our immediate compliance requirements and support our longer-range business, financial and operational goals in an efficient and cost-effective manner."

"Forward-thinking firms like PepsiAmericas are turning to Certus to help them balance their short-term sign-off requirements with their long-term objectives of sustained compliance and improved business efficiencies," said Vani Kola, president and CEO, Nth Orbit. "We are excited that they have made Certus their solution of choice, and have joined such industry leaders as Polaroid, Great-West Life \& Annuity Insurance Firm and Suntron in putting Nth Orbit's products and expertise at the forefront of their Sarbanes-Oxley initiative."

\section{Example of Press Release for Firm Making SOX-related ICM technology Announcement for Compliance Role}

COLT Telecom Group Selects OpenPages SOX Express for Sarbanes-Oxley Compliance

DATELINE: WALTHAM, Mass., July 13, 2004

COLT will deploy SOX Express to streamline its internal control documentation process across all of its locations. It will enable the collection of information regarding ongoing business controls deployment and monitoring, resulting in a reduction of compliance costs. By combining a strong document repository with powerful compliance automation capabilities, SOX Express will facilitate both project management and compliance, using web-based tools to get users up to speed quickly.

"OpenPages has strong functionality for compliance and a simple interface for end users," said Gerry Small, international finance director at COLT Telecom Group. "We felt that OpenPages demonstrated a clear enterprise compliance vision, and backed it up with a commitment to product quality and customer satisfaction."

OpenPages' SOX Express is an enterprise compliance management solution that reduces the time and resource costs associated with ongoing compliance for Sections 302 and 404. SOX Express is a focused enterprise application that combines powerful document and business process management with flexible reporting capabilities in an extremely easy-to-use environment that enables CEOs, CFOs and financial management officers to enforce internal controls. SOX Express helps corporations automate significant aspects of their internal controls framework to significantly reduce the overall cost of compliance. Its dashboards can be used by project managers, documentation team members, internal auditors and external auditors to plan, document and test the internal controls of the firm, and eventually to attest to the financial statements. 